\title{
Physical and optical properties of 2010 Eyjafjallajökull volcanic eruption aerosol: ground-based, Lidar and airborne measurements in France
}

\author{
M. Hervo ${ }^{1}$, B. Quennehen ${ }^{1}$, N. I. Kristiansen ${ }^{3}$, J. Boulon ${ }^{1}$, A. Stohl ${ }^{3}$, P. Fréville ${ }^{1}$, J.-M. Pichon ${ }^{1}$, D. Picard ${ }^{1}$, \\ P. Labazuy ${ }^{2}$, M. Gouhier ${ }^{2}$, J.-C. Roger ${ }^{1}$, A. Colomb ${ }^{1}$, A. Schwarzenboeck ${ }^{1}$, and K. Sellegri ${ }^{1}$ \\ ${ }^{1}$ Laboratoire de Météorologie Physique, UMR6016, Observatoire de Physique du Globe de Clermont-Ferrand, CNRS - \\ Université Blaise Pascal, Clermont-Ferrand, France \\ ${ }^{2}$ Laboratoire Magma et Volcan, Observatoire de Physique du Globe de Clermont-Ferrand, CNRS - Université Blaise Pascal, \\ Clermont-Ferrand, France \\ ${ }^{3}$ Norwegian Institute for Air Research, Kjeller, Norway
}

Correspondence to: M. Hervo (m.hervo@opgc.univ-bpclermont.fr)

Received: 25 July 2011 - Published in Atmos. Chem. Phys. Discuss.: 1 September 2011

Revised: 18 January 2012 - Accepted: 31 January 2012 - Published: 16 February 2012

\begin{abstract}
During the Eyjafjallajökull eruption (14 April to 24 May 2010), the volcanic aerosol cloud was observed across Europe by several airborne in situ and ground-based remote-sensing instruments. On 18 and 19 May, layers of depolarizing particles (i.e. non-spherical particles) were detected in the free troposphere above the Puy de Dôme station, (PdD, France) with a Rayleigh-Mie LIDAR emitting at a wavelength of $355 \mathrm{~nm}$, with parallel and crossed polarization channels. These layers in the free troposphere (FT) were also well captured by simulations with the Lagrangian particle dispersion model FLEXPART, which furthermore showed that the ash was eventually entrained into the planetary boundary layer (PBL). Indeed, the ash cloud was then detected and characterized with a comprehensive set of in situ instruments at the Puy de Dôme station (PdD). In agreement with the FLEXPART simulation, up to $65 \mu \mathrm{g} \mathrm{m}^{-3}$ of particle mass and $2.2 \mathrm{ppb}$ of $\mathrm{SO}_{2}$ were measured at $\mathrm{PdD}$, corresponding to concentrations higher than the 95 percentile of $2 \mathrm{yr}$ of measurements at PdD. Moreover, the number concentration of particles increased to $24000 \mathrm{~cm}^{-3}$, mainly in the submicronic mode, but a supermicronic mode was also detected with a modal diameter of $2 \mu \mathrm{m}$. The resulting optical properties of the ash aerosol were characterized by a low scattering Ångström exponent (0.98), showing the presence of supermicronic particles. For the first time to our knowledge, the combination of in situ optical and physi-
\end{abstract}

cal characterization of the volcanic ash allowed the calculation of the mass-to-extinction ratio $(\eta)$ with no assumptions on the aerosol density. The mass-to-extinction ratio was found to be significantly different from the background boundary layer aerosol (max: $1.57 \mathrm{~g} \mathrm{~m}^{-2}$ as opposed to $0.33 \pm 0.03 \mathrm{~g} \mathrm{~m}^{-2}$ ). Using this ratio, ash mass concentration in the volcanic plume derived from LIDAR measurements was found to be $655 \pm 23 \mu \mathrm{g} \mathrm{m}^{-3}$ when the plume was located in the FT ( $3000 \mathrm{~m}$ above the sea level - a.s.l.).

This ratio could also be used to retrieve an aerosol mass concentration of $579 \pm 60 \mu \mathrm{g} \mathrm{m}^{-3}$ on 19 April, when LIDAR observations detected the ash cloud at $3000 \mathrm{~m}$ a.s.l. in correspondence with model simulations (FLEXPART). On 22 April, another ash plume entered the BL, and although it was more diluted than during the May episode, the French research aircraft ATR42 that passed over Clermont-Ferrand in the PBL confirmed the presence of particles with a supermicronic mode, again with a modal diameter at $2 \mu \mathrm{m}$.

This data set combining airborne, ground-based and remote sensing observations with dispersion model simulations shows an overall very good coherence during the volcanic eruption period, which allows a good confidence in the characteristics of the ash particles that can be derived from this unique data set. 


\section{Introduction}

On 20 March 2010, a volcanic eruption started in the Fimmvörduháls pass between two central volcanoes, Eyjafjallajökull and Katla, in the southern part of Iceland, about $150 \mathrm{~km}$ east of Reykjavik. Lava fountains up to $200 \mathrm{~m}$ height characterized this first eruption phase, but the activity at Fimmvörduháls eventually ceased on 13 April 2010. A few hours later, seismic unrest was detected $20-25 \mathrm{~km}$ beneath the summit crater of Eyjafjallajökull $\left(63.63^{\circ} \mathrm{N}, 19.62^{\circ} \mathrm{W}\right.$, $1666 \mathrm{~m}$ a.s.l.), and a long eruptive fissure opened in the above glacier ejecting a more silicic magma than before, and leading to a large phreatomagmatic eruption (Sigmundsson et al., 2010). This type of eruption is characterized by highly explosive phases due to magma-water interaction increasing pyroclasts' fragmentation, which may partly explain the very large amount of fine ash released into the atmosphere. The eruption has been characterized by two main phases of intense ash and gas emissions spanning 14-21 April and 1-18 May (Stohl et al., 2011), with a maximum intensity recorded on 6 May. The ash and gas emissions ceased on 24 May after about 6 weeks of intense ash emissions. Satellite-based measurements carried out with Meteosat Second Generation (MSG), Spin-stabilised Enhanced Visible and Infrared Imager (SEVIRI) and Aura-OMI sensors give a total fine ash mass estimate of $4.8 \mathrm{Mt}$ centred on $4.3 \mu \mathrm{m}$ and $0.2 \mathrm{Mt}$ of sulphur dioxide $\left(\mathrm{SO}_{2}\right)$ (Labazuy et al., 2012), whereas an inversion study using SEVIRI and IASI satellite data obtained a total fine ash mass of $8.3 \mathrm{Mt}$ in the size range $2.8-28 \mu \mathrm{m}$ (Stohl et al., 2011). Volcanic ash and gas clouds are a threat to aircraft operations (Prata and Tupper, 2009; Casadevall, 1994) and concerns about aviation safety led to repeated closure of large parts of the European airspace during periods of the Eyjafjallajökull eruption. This caused global travel chaos and the loss of billions of Euro and directly impacted millions of people.

The presence of volcanic ash in April-May 2011 has been demonstrated all over Europe through several studies. Different techniques were used aiming to determine the properties of ash particles/clouds. Airborne in situ measurements were performed in the ash cloud by the German Falcon research aircraft (Schumann et al., 2011), measuring ash volume size distribution with a effective diameters between 0.2 and $3 \mu \mathrm{m}$, while the Swiss Diamond Aircraft HK36 (Bukowiecki et al., 2011) flew to track the ash plume over Switzerland and measured high particle concentrations over Zurich, up to $120 \mathrm{~cm}^{-3}$ for particle larger than $500 \mathrm{~nm}$.

In the same study, Bukowiecki et al. (2011) present ground-based measurement at an elevated site in the Swiss Alps (Jungfraujoch). Unusual enhancements in $\mathrm{SO}_{2}$ up to $25 \mu \mathrm{g} \mathrm{m}^{-3}$, particulate matter $\left(\mathrm{PM}_{10}\right)$ concentrations up to $70 \mu \mathrm{g} \mathrm{m}^{-3}$ and a mean optical diameter around $3 \pm 0.3 \mu \mathrm{m}$ were detected. Additionally, hygroscopicity was also investigated and reveals that ash uptakes water efficiently via adsorption (Lathem et al., 2011). Other high-altitude sta- tions recorded ash episodes combined with sulphuric dioxide and sulphuric acid enhancements in Germany (Flentje et al., 2010; Schäfer et al., 2011) while at sea-level, measurement stations also detected ashes (Lettino et al., 2012; Pitz et al., 2011).

While RADAR is intensely used close to the volcano to monitor the ash emissions, remote sensing by LIDAR is the most common technique used to detect aerosols in the atmosphere after transport far from the source. The largest ash particles settle close to the eruption site while micrometric particles can remain airborne longer and can be transported far down-wind from the volcano. Most of LIDAR measurement stations are grouped in a dedicated network (European Aerosol Research Lidar Network to Establish an Aerosol Climatology: EARLINET) and their results are presented by Ansmann et al. (2011). They report an enhancement in the depolarization ratio, an indicator of the particle non-sphericity and in the extinction coefficient, which indicates important concentrations of large particles. Similar results are presented by several studies all over Europe (Mona et al., 2011; Emeis et al., 2011; Revuelta et al., 2012; Miffre et al., 2012; Gasteiger et al., 2011).

To convert the Lidar signal into mass concentration, a mass-to-extinction ratio $(\eta)$ is needed. In the studies-cited above, $\eta$ values could not be calculated directly because collocated in situ measurements were missing. For example, Miffre et al. (2012) assume an ash diameter of $10 \mu \mathrm{m}$ and a density of $2.6 \mathrm{~g} \mathrm{~cm}^{-3}$ (Miffre et al., 2012). Ansmann et al. derived a particle mass concentration from a LidarPhotometer synergy with assumptions on density (Ansmann et al., 2011) and Gasteiger et al. from a Bayesian inference statistical method with assumptions on the particle shape or on the size distribution (Gasteiger et al., 2011).

In this study, we present a combination of in situ and collocated Lidar extinction measurements, operated by the OPGC (Observatoire de Physique du Globe de Clermont-Ferrand) on two different occasions during April and May 2010. The ash plume was further studied by analyzing the output from particle dispersion model simulations and airborne measurements. We present microphysical and optical properties of the volcanic ash after transport in the atmosphere and a quantitative study of the mass concentration derived from the synergy between these measurements.

\section{Instrumentation and modelling}

\subsection{The Puy de Dôme research station}

The Puy de Dôme (PdD) research station is located in the centre of France $\left(45^{\circ} 46^{\prime} \mathrm{N}, 2^{\circ} 57^{\prime} \mathrm{E}\right)$ at $1465 \mathrm{~m}$ a.s.l. The station is equipped with state of the art instrumentation operated continuously to characterise aerosol particles and trace gases including $\mathrm{SO}_{2}$ concentrations. Results showing the seasonal variation of the aerosol number size distribution 
are discussed in Venzac et al. (2009). All the in situ instruments presented in this paper measure the dry aerosol properties and are sample after the inlet with a cut-off diameter of $30 \mu \mathrm{m}$.

Particle number concentrations with a diameter greater than $10 \mathrm{~nm}$ are measured with a butanol based CPC (model TSI 3010). Total mass concentrations of aerosol particles are measured with the commercial instrument: TEOMFDMS 8500C (Tapered Element Oscillating MicrobalanceFilter Dynamic Measurement System, Grover et al., 2005; Ruppecht et al., 1992). The TEOM-FDMS uses intermittent sampling through a filter to account for the mass of semi-volatile material lost due to volatilization. The resolution of the TEOM-FDMS given by the constructor is $2.5 \mu \mathrm{m}^{-3} \pm 1 \%$ of the measurement. The aerosol absorption coefficient $\sigma_{\mathrm{abs}}$ is measured with a Multi Angle Absorption Photometer (MAAP 5012; with a central wavelengths at $637 \mathrm{~nm}$, Petzold et al., 2005), and the scattering (and backscattering) coefficient by a three wavelengths nephelometer (model TSI 3563 with central wavelengths of 450 , $550,700 \mathrm{~nm}$ ) for which corrections for detection limits and truncation errors are applied (Anderson and Ogren, 1998).

The nephelometer data allow the calculation of the scattering Ångström exponent $(\alpha)$ between two wavelengths:

$\alpha=-\frac{\log \sigma_{\mathrm{sca}(700 \mathrm{~nm})}-\log \sigma_{\mathrm{sca}(450 \mathrm{~nm})}}{\log 700-\log 450}$

A scattering Ångström exponent $(\alpha)$ value around 2 implies an aerosol volume size distribution with scattering $\left(\sigma_{\text {sca }}\right)$ dominated by small particles (diameter $<1 \mu \mathrm{m}$ ), while a volume distribution dominated by coarse particles $(\mathrm{Dm}>1 \mu \mathrm{m})$ has typically a smaller $\alpha$, around 1 (Dubovik et al., 2002).

The scattering properties are calculated at $355 \mathrm{~nm}$ using the scattering Ångström exponent $(\alpha)$. According to previous studies the uncertainties on the scattering coefficient can be consider of $7 \%$ (Anderson and Ogren, 1998; Anderson et al., 1999). After propagation (Wagner and Silva, 2008), the value of the error in the calculation of $\alpha$ was determined $(\Delta \alpha=0.32)$. Extrapolating the scattering coefficient at $355 \mathrm{~nm}$, from measurements at $450 \mathrm{~nm}$ and the Ångström exponent, generates an error of $19 \%$ with the following equation:

$$
\frac{\Delta \sigma_{\mathrm{sca}(355)}}{\sigma_{\mathrm{sca}(355)}}=\ln \left(\frac{637}{450}\right) \Delta \alpha+\frac{\Delta \sigma_{\mathrm{sca}(450)}}{\sigma_{\mathrm{sca}(450)}}
$$

The MAAP and nephelometer measurements enable to calculate the single scattering albedo $\omega_{0}$ :

$$
\omega_{0(\lambda)}=\frac{\sigma_{\mathrm{sca}(\lambda)}}{\sigma_{\mathrm{sca}(\lambda)}+\sigma_{\mathrm{abs}(\lambda)}}
$$

$\omega_{0}$ indicates the relative absorptivity of the aerosol, with lower values indicating stronger absorption.
A combination of the TEOM, MAAP and nephelometer measurements can be used to calculate the mass-toextinction conversion factor $\eta$ at a specific wavelength $\lambda$,

$\eta_{(\lambda)}=\frac{M}{\sigma_{\text {sca }(\lambda)}+\sigma_{\text {abs }(\lambda)}}$

where $M$ is the total mass concentration measured by the TEOM. $\eta$ is a key parameter to calculate vertically-resolved mass concentration from Lidar measurements.

The absorption coefficient is calculated at $355 \mathrm{~nm}$ with an Absorption Ångström Exponent (AAE) equal to unity (i.e. the absorption is directly proportional to the wavelength variation: $\left.\sigma_{\mathrm{abs}(355)} \approx 637 / 355 \cdot \sigma_{\mathrm{abs}(637)}\right)$. AAE is correlated with aerosol composition or type: for most urban industrial site, the AEE value is close to one but can increase until 2.5 for others kind of particle (Russell et al., 2010). Using an AAE of $1\left(\sigma_{\mathrm{abs}(355)}=1.79 \cdot \sigma_{\mathrm{abs}(637)}\right)$ instead of 2.5 $\left(\sigma_{\mathrm{abs}(355)}=4.31 \cdot \sigma_{\mathrm{abs}(637)}\right)$ implies an important error on the absorption coefficient by a factor of 2.41. Nevertheless, as the single scattering albedo is relatively high $(0.97 \pm 0.01)$ during the measurement period (i.e. the scattering coefficient is significantly higher than absorption coefficient) the absorption impact on the extinction is limited. Indeed the extinction was calculated for both AAE of 1 and 2.5 in order to estimate the error generated by such an approximation. When using the AAE of 1 instead of 2.5, the extinction was underestimated by only $4.2 \%$ on average with a $10.4 \%$ maximum on the period considered in this study. The same error will be propagated to the mass-to-extinction ratio $\eta$ and to the Lidar mass concentration.

The supermicronic Particle Size Distributions (PSD) are recorded with an Optical Particle Counter (OPC, Grimm model 1.108) measuring particles in the size range $0.3<\mathrm{Dm}<20 \mu \mathrm{m}$ over 16 channels. Submicronic PSD are detected using a Scanning Mobility Particle Sizer (SMPS, Villani et al., 2008), sizing particles in the range $10<\mathrm{Dm}<500 \mathrm{~nm}$.

$\mathrm{SO}_{2}$ concentrations are measured by a pulsed fluorescence gas analyzer (TEI 43CTL), while nitrogen dioxide $\left(\mathrm{NO}_{2}\right)$ and nitrogen monoxide (NO) are measured by ozone chemiluminescence (TEI 42CTL), $\mathrm{O}_{3}$ with a UV analyser (TEI 49C) and CO with a IR analyser (TEI $42 \mathrm{TL}$ ). The chemical composition of the aerosol is determined 2 days a week by Teflon filter samples collected following GAW (Global Atmosphere Watch) recommendation (WMO, 2003) and analysed by ionic chromatography (DIONEX). Analytical procedures are described in Bourcier (2009).

\subsection{Lidar}

We used a Raymetrics Rayleigh-Mie Lidar, based on a tripled $\mathrm{Nd}$ :YAG frequency laser, which emits pulses of $75 \mathrm{~mJ}$ output energy at $355 \mathrm{~nm}$ with a $10 \mathrm{~Hz}$ repetition rate, on parallel and orthogonal polarization channels. The optical receiver is a Cassegrainian reflecting telescope with a primary mirror 
of $300 \mathrm{~mm}$ diameter and a focal length of $600 \mathrm{~mm}$, directly coupled, through an optical fibre, to the Lidar signal multichannel detection box (Papayannis et al., 2005). The vertical resolution of the raw signals is $7.5 \mathrm{~m}$. The Lidar is positioned on the roof of the OPGC, $\left(45.76^{\circ} \mathrm{N}, 3.11^{\circ} \mathrm{E}\right)$ at $425 \mathrm{~m}$ a.s.l. (located $11 \mathrm{~km}$ east of PdD).

As the Lidar measures both parallel and orthogonal polarization it allows us to calculate the volume depolarization ratio as a function of the distance $r$ from the telescope $\delta(r)$ (Weitkamp, 2005). A large depolarization ratio indicates that the aerosol is strongly depolarizing and, thus, that particles are non-spherical. Non-spherical glass and mineral particles typical of volcanic ash generate strong laser depolarization (Sassen et al., 2007).

The Lidar signal inversion is based on the Klett method (Klett, 1985) to obtain the aerosol extinction $\alpha_{\text {aer }}$ from the measured backscatter $\beta_{\text {aer }}$. The inversion needs a particle free Lidar signal (typically between $6000 \mathrm{~m}$ and $8000 \mathrm{~m}$ ) and therefore can only be realised during clear sky conditions. Typical statistical errors due to the signals detection are below $10 \%$ for backscatter coefficients at $355 \mathrm{~nm}$. (Matthais et al., 2004; Giannakaki et al., 2010; Bockmann et al., 2004). For each Lidar profile, an aerosol Lidar ratio $\left(L_{\text {aer }}\right)$ can be calculated according to the following equation:

$L_{\mathrm{aer}}=\frac{4 \pi}{\omega_{0} P_{11}\left(180^{\circ}\right)}=\frac{\alpha_{\mathrm{aer}}}{\beta_{\mathrm{aer}}}$

With $\omega_{0}$ the single scattering albedo and $P_{11}\left(180^{\circ}\right)$ the phase function at $180^{\circ}$ computed with a Mie code (Bond et al., 2006; Mätzler, 2002). The Mie code inputs are the size distribution and the refractive index. The size distribution is measured with the SMPS and OPC. The refractive index was obtained via an inversion of the dry scattering and absorption, using Mie theory and the measured size distribution.

\subsection{Aircraft measurements}

During the Eyjafjalla eruption, the French research aircraft ATR-42 was deployed over France. In order to estimate concentrations of volcanic ash in the atmosphere, two microphysical probes were mounted on the aircraft: the Passive Cavity Aerosol Spectrometer Probe (PCASP 100-X, DMT) and the Forward Scattering Spectrometer Probe (FSSP-300, DMT) measuring in particle size ranges $0.1 \mu \mathrm{m}<\mathrm{Dm}<3 \mu \mathrm{m}$ and $0.3 \mu \mathrm{m}<\mathrm{Dm}<20 \mu \mathrm{m}$ over 30 and 31 channels, respectively. The instruments were operating outside the aircraft fuselage. From 19 to 22 April, four scientific flights were performed over France, and on 22 April, the ATR-42 flew over Clermont-Ferrand in the PBL.

\subsection{FLEXPART simulations}

We used the Lagrangian particle dispersion model FLEXPART (Stohl et al., 2005) to evaluate the presence of the volcanic ash cloud over our two measuring sites. FLEXPART was run in forward mode and driven with meteorological data from the European Centre for Medium-Range Weather Forecasts (ECMWF) analyses with $0.18 \times 0.18^{\circ}$ horizontal resolution and 91 vertical model levels. The simulation accounted for gravitational particle settling as well as dry and wet deposition, but no ash aggregation processes. Formation of sulphate particles was also not simulated. The ash emission rates and heights were determined using an inversion scheme that couples a priori source information and FLEXPART model data with satellite data (Stohl et al., 2011). The ash particle size distribution included 25 particle size classes from $0.25-250 \mu \mathrm{m}$ diameter. The model output had a spatial resolution of $0.25 \times 0.25^{\circ}$ and a vertical resolution of $250 \mathrm{~m}$.

\subsection{Uncertainties discussion}

All the variabilities given in the following results represent the standard deviation of the parameter during the considered period.

The uncertainties on the mass-to-extinction ratio have been calculated following this equation:

$$
\Delta \eta=\frac{1}{\sigma_{\mathrm{abs}}+\sigma_{\mathrm{sca}}}\left(\Delta M+M \frac{\Delta \sigma_{\mathrm{abs}}+\Delta \sigma_{\mathrm{sca}}}{\sigma_{\mathrm{abs}}+\sigma_{\mathrm{sca}}}\right)
$$

where $\Delta \eta$ are the uncertainties on the mass-to-extinction ratio, $\Delta M$ the error on the mass measurements $M$ given by the TEOM constructor, $\Delta \sigma_{\text {sca }}$ and $\Delta \sigma_{\text {abs }}$ respectively the uncertainties on the measured scattering and absorption coefficients at $355 \mathrm{~nm}\left(\sigma_{\mathrm{sca}}\right.$ and $\left.\sigma_{\mathrm{abs}}\right)$. During the volcanic event the mean relative uncertainties is $33 \%$. Now the uncertainties are represent on Fig. 5.

A sensitivity of the impact of non-sphericity on Lidar ratio has been done the 28 June 2011, when strongly depolarizing particle and photometer measurements were present $(\delta>40 \%)$. The Lidar ratio retrieve with the synergy of Lidar and photometer (Raut and Chazette, 2007; Cuesta et al., 2008) was $75 \mathrm{Sr}^{-1}$. The difference with the Lidar ratio computed with the procedure described previously is lower than $18 \%$. The same procedure was proceeded on the 11 June 2011 when no depolarizing particles were detected. The difference between both Lidar ratios was $5 \%$.

The estimations of the Lidar ratio derivate from Lidar/Sun photometer is expected in the range 15-25\% (Nehrir et al., 2011; Dubovik and King, 2000). Consequently we assume that using a Mie code instead of the most common method (Lidar/Photometer synergy) is not the main factor of uncertainties. A last the Lidar ratio retrieved with our procedure is close to the Lidar ratio retrieved with the most accurate methods describe previously.

When maximizing the uncertainties of all the parameters, the precision of the mass retrieved is better than $68 \%$. 

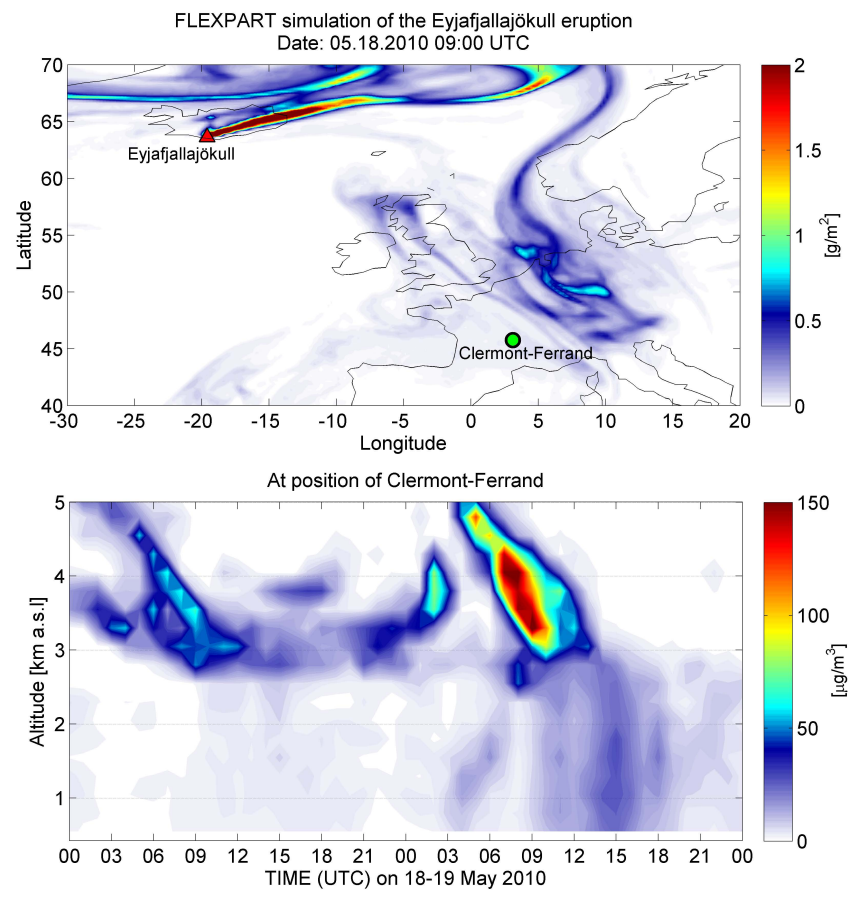

Fig. 1. FLEXPART simulated ash cloud. Total ash column load on 18 May 09:00 UTC (upper panel), and simulated vertical distribution of ash over Clermont-Ferrand for 18 and 19 May (lower panel).

\section{Results}

\subsection{Case 1: 18 and 19 May 2010}

\subsubsection{Simulated ash distribution}

On 18 and 19 May, the Eyjafjalla volcanic cloud resided over Clermont-Ferrand. Figure 1 (upper panel) shows the FLEXPART simulated distribution of the ash clouds over Europe at 09:00 UTC on 18 May. The ash cloud arrived from the north and parts of the cloud were sampled previously on 17 May over the North Sea and on 18 May over Germany by a research aircraft (Schumann et al., 2011). High ash concentrations of up to $500 \mu \mathrm{g} \mathrm{m}^{-3}$ were found on 17 May and still high concentrations were observed over Germany on 18 May, in relatively good agreement with the FLEXPART simulated concentrations along the aircraft flight tracks (Stohl et al., 2011). Figure 1 (lower panel) shows a time-height section of the FLEXPART simulated ash mass concentrations over Clermont-Ferrand. FLEXPART is simulating volcanic ash around $3000 \mathrm{~m}$ a.s.l. above Clermont-Ferrand from 00:00 UTC on 18 May to 13:00 on 19 May. The maximum ash mass concentration is $176 \mu \mathrm{g} \mathrm{m}^{-3}$ at 08:00 UTC on 19 May at $4100 \mathrm{~m}$ a.s.l. On two occasions (on 19 May from 03:00 UTC to 08:00 and from 10:00 to 20:00), FLEXPART simulates entrainment of volcanic ash into the boundary layer.

\subsubsection{Lidar measurements}

The Lidar observations (Fig. 2 top pannel) highlight the presence of a depolarizing layer in the free troposphere (FT) at $3000 \mathrm{~m}$ a.s.l, from 04:00 to 10:00 on 18 May, with a maximum thickness of $500 \mathrm{~m}$. At 10:00 UTC, cumulus clouds are formed at the same altitude as the volcanic cloud. The layer was observed again on 19 May from 06:00 (after the clouds have dissipated) to 24:00 UTC. The depolarization shows a maximum of around $19 \%$ for 18 May and $25 \%$ for 19 May. The Lidar observations of the Eyjafjalla's ash cloud mostly agree in time and relative intensity with the FLEXPART simulations. Nevertheless the altitude of the FLEXPART simulation is shifted by around $500 \mathrm{~m}$ towards higher altitudes compared to the Lidar observations. On 19 May, the maximum intensity of both Lidar observations and FLEXPART simulation is shown around 08:00. Moreover, the simulated cloud was dissipated when the intensity of the Lidar observation began to decrease (around 13:00) but the presence of less concentrated volcanic ash after this dissipation is not shown in FLEXPART.

The Lidar observations also revealed twice the presence of non-spherical particles in the boundary layer. The first observation occurred between 23:30 UTC on 18 May and 04:00 UTC on 19 May, and the second between 09:45 UTC and 22:00 UTC on 19 May. While FLEXPART simulated a nearly instantaneous mixing process in the PBL at 09:00 on 18 May, the non-spherical particle layer was bounded at an upper altitude of $1250 \mathrm{~m}$ a.s.l. at 23:30 UTC, which increases gradually with time to reach $2500 \mathrm{~m}$ a.s.l. at 04:00 on 19 May. On the contrary, a perfect agreement was reached between simulations and observations for the cloud on 19 May with the maximum intensity of the cloud found between 15:00 and 16:00 UTC.

\subsubsection{In-situ measurements at PdD}

The PdD site is located about $11 \mathrm{~km}$ to the west of the Lidar site, which could explain small differences in the timing and intensity of ash events at the two sites and higher topography makes the model simulation more difficult.

Figure $2 \mathrm{~b}$ shows that $\mathrm{SO}_{2}$ concentrations significantly increased on 18 and 19 May, reaching 2.2 ppb from 23:45 UTC on 18 May to 05:20 UTC on 19 May, and from 09:50 to 18:00 UTC on 19 May. This is above the 99th percentile calculated over the last $2 \mathrm{yr}(1.69 \mathrm{ppb})$. The enhancement of $\mathrm{SO}_{2}$ concentration coincides exactly with the Lidar detection of depolarizing particles detected in the PBL. $\mathrm{NO}_{2}$, $\mathrm{NO}, \mathrm{CO}$ and $\mathrm{O}_{3}$ concentrations did not show simultaneous variations, suggesting that the $\mathrm{SO}_{2}$ did not come from local anthropogenic sources. The $\mathrm{NO}_{2} / \mathrm{NO}_{\mathrm{x}}$ ratio is close to 1 $(0.94 \pm 0.06)$, indicating again that the pollution was not related to local traffic emissions, which are rich in NO (Soltic and Weilenmann, 2003). 


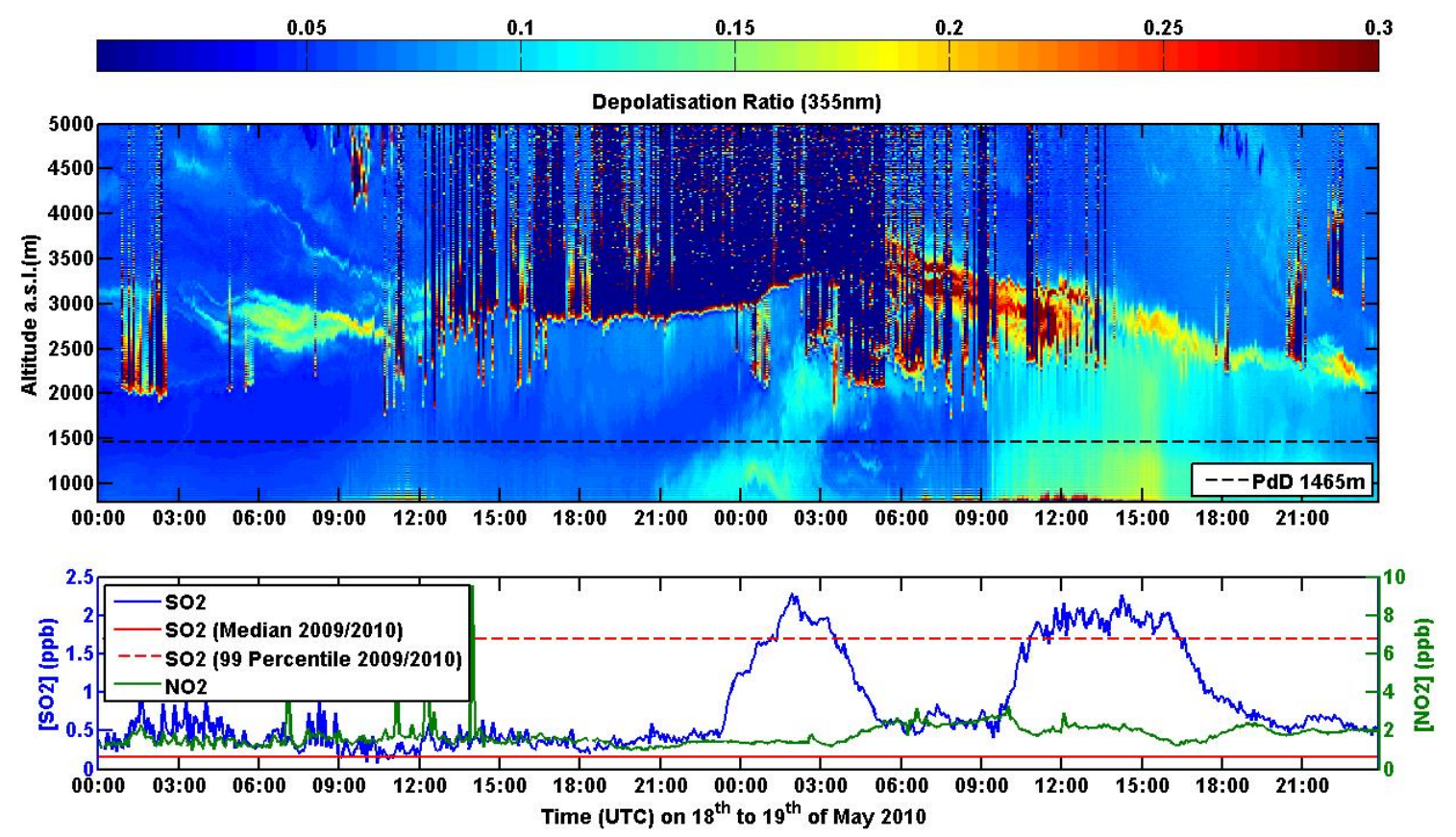

Fig. 2. Top panel: time series of volume depolarization ratio derived from the Lidar data. The black dashed line represents the height of the Puy de Dôme measurement station (1465 m a.s.1.). Bottom: $\mathrm{SO}_{2}$ and $\mathrm{NO}_{2}$ concentrations at PdD for the same period. The red dash line indicates the 99-percentile of $\mathrm{SO}_{2}$ concentrations observed in 2009 and 2010 and the continuous red line the median.

Moreover, the $\mathrm{SO}_{4}^{2-}$ concentration collected on the Teflon filter from 18-19 May, $1.83 \mu \mathrm{g} \mathrm{m}^{-3}$, is six times higher than the median annual concentration $\left(0.32 \mu \mathrm{g} \mathrm{m}^{-3}\right)$ and above the 90th percentile $\left(1.73 \mu \mathrm{g} \mathrm{m}^{-3}\right)$. The volcanic $\mathrm{SO}_{2}$ was transported jointly with the non-spherical particles (Fig. $2 \mathrm{~b}$ ) like suggest by Thomas and Prata (2011). The presence of ash particles was confirmed by two independent devices: the TEOM instrument showed an increase of the mass concentration from 20 up to $65 \mu \mathrm{g} \mathrm{m}^{-3}$ (Fig. 3b) and the nephelometer light scattering measurements allowed to calculate the scattering Ångström exponent $(\alpha)$, which decreased from $1.9 \pm 0.1$ to 0.97 (Fig. 3a). The single scattering albedo did not vary significantly with a value of $0.97 \pm 0.01$. In addition, concentrations of the total number of particles (Diameter $>10 \mathrm{~nm}$ ) measured by the CPC 3010 increased significantly. This was related to sulphuric acid droplet nucleation events as suggested by Schumann et al. (2011) and shown by Boulon et al. (2011). Altogether, these data clearly indicate that volcanic ash were present in the boundary layer at the PdD station.

The total aerosol mass concentrations detected at PdD are also compared to the ash mass concentrations simulated by FLEXPART (Fig. 3b). Time variations of measured and simulated mass concentrations show the same pattern, although simulated ash mass concentrations are on average 4.5 times lower than the observations during the volcanic event. Two factors can explain at least partly the difference: first the background aerosol is not considered in the FLEXPART simulation. Therefore, FLEXPART is expected to show lower mass concentrations than the measurements, especially when the ash mass contributions are low. When adding the background mass concentration to the FLEXPART results as a rough estimate of the mass contributions from non-volcanic sources, the agreement is improved substantially. Secondly, FLEXPART does not simulate the formation of sulphate aerosol, which contributes to the measured aerosol mass concentration in the volcanic cloud.

The OPC and SMPS were operating from 19 May at 12:00, the volume size distribution shown a clear maximum at $1.8 \mu \mathrm{m}$ until $15: 45$ with a maximum concentration of $2.15 \mathrm{~cm}^{-3}$ at $14: 15$ (Fig. 4). It is higher than the 99th percentile $\left(1.8 \mathrm{~cm}^{-3}\right)$ measured for this diameter in 2010 and more than 10 times larger than the median $\left(0.2 \mathrm{~cm}^{-3}\right)$. The number size distribution measured at the PdD is centred on $2 \mu \mathrm{m}$, corresponding to the presence of volcanic ash as detected from the Lidar and other indicators such as the $\mathrm{SO}_{2}$ concentrations. During this period, the total aerosol mass concentration derived from the size distribution $(10 \mathrm{~nm}$ to $20 \mu \mathrm{m})$, assuming an ash density of $2.6 \mathrm{~g} \mathrm{~cm}^{-3}$ given by OPAC software for mineral (Hess et al., 1998), is $39.2 \pm 3.7 \mu \mathrm{g} \mathrm{m}^{-3}$. This is in good agreement, within the given variabilities, with the TEOM mass concentration of $52 \pm 9 \mu \mathrm{g} \mathrm{m}^{-3}$ reported above. These values can be compared to the $13 \pm 4 \mu \mathrm{g} \mathrm{m}^{-3}$ of ash simulated by FLEXPART, indicating that either the volcanic aerosol would contribute by roughly $30 \%$ of the total aerosol mass in the $\mathrm{BL}$, or that the FLEXPART simulation underestimates the ash mass concentration. We may investigate the two options by considering 

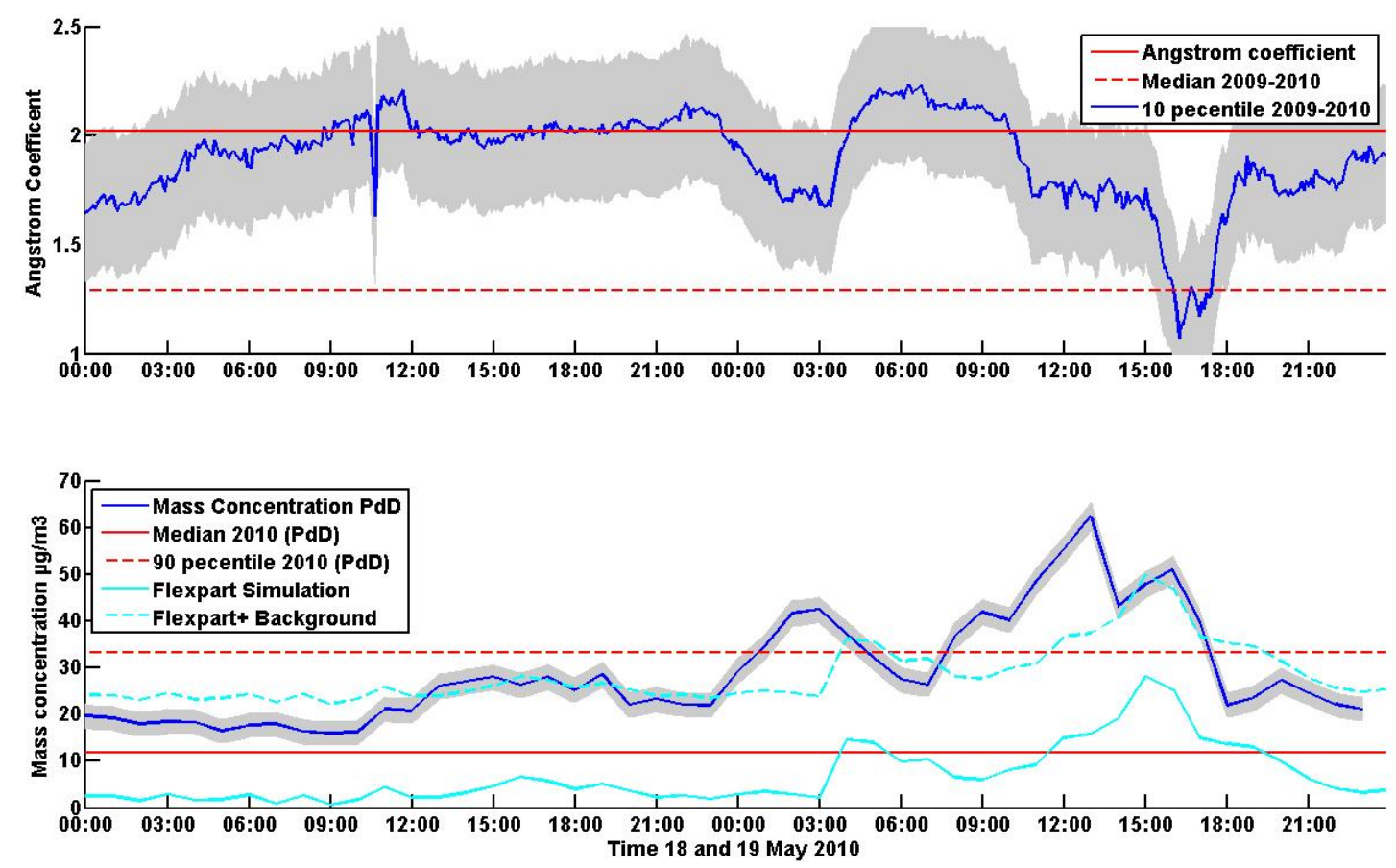

Fig. 3. Top panel: Ångström coefficient for the 18 and 19 May. The continuous red line indicates the median observed in 2009 and 2010 and the dotted line represents the 10th percentile. Bottom panel: mass concentration in $\mu \mathrm{g} \mathrm{m}^{-3}$ measured by the TEOM in blue and simulated by FLEXPART at the Puy de Dôme height for the same date. The continuous red line indicates the median measured in 2010 and the dotted line represents the 90th percentile. The dotted cyan line represents the FLEXPART simulated mass plus the background measured before the volcanic event.

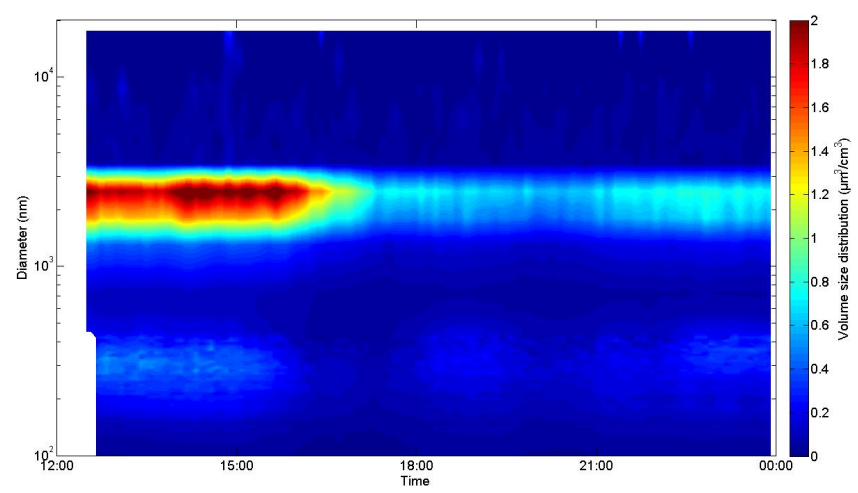

Fig. 4. Particle volume size distribution measured by a SMPS and Grimm OPC on 19 May 2010 at the Puy de Dôme.

the average aerosol mass which was measured just before the ash plume entered the $\mathrm{BL}\left(21.6 \pm 4.4 \mu \mathrm{g} \mathrm{m}^{-3}\right.$ on 18 May). By using this value as a background concentration, we achieve a $60 \%$ contribution of the volcanic aerosol to the total mass during the plume intrusion, and a $33 \%$ underestimation of the FLEXPART ash simulations. Again, the FLEXPART underestimation can be partly explained by the fact that the model does not simulate the formation of secondary aerosols.

\subsubsection{Mass extinction ratio calculation}

Simultaneous in situ measurements of the aerosol total mass and of the aerosol optical properties are a unique chance to characterize the mass-extinction ratio ( $\eta$, Eq. 4) usually used for retrieving the aerosol mass from Lidar observations. To our knowledge, in situ measurements are the only way to calculate $\eta$ with no assumption on the density of individual particles.

Figure 5 shows the evolution of mass-to-extinction ratio $\eta$ for 18 and 19 May. It clearly indicates a first enhancement from 00:00 to 04:00 on 19 May, and a second increase from 10:00 to 22:00 UTC with a maximum between 15:00 and 17:00 UTC on 19 May that corresponds to the volcanic measurements previously presented.

The mean $\eta$, before the presence of the volcanic eruption cloud was $0.33 \mathrm{~g} \mathrm{~m}^{-2}( \pm 0.03)$. It is slightly higher than the values measured by Raut and Chazette around Paris $\left(0.21 \mathrm{~g} \mathrm{~m}^{-2}\right)$ (Raut and Chazette, 2009) but similar to the median calculated all over the year at $\operatorname{PdD}\left(0.36 \mathrm{~g} \mathrm{~m}^{-2}\right)$.

During the onset of the event, from 10:00 to 22:00 on 19 May, $\eta$ increased to $0.61 \mathrm{~g} \mathrm{~m}^{-2}( \pm 0.31)$ and further to a maximum of $1.57 \mathrm{~g} \mathrm{~m}^{-2}$ during the main event. Those values have the same order of magnitude than those inverted from the multi wavelength Lidar sounding over Maisach, Germany, during the Eyjafjalla ash observations on 17 April 


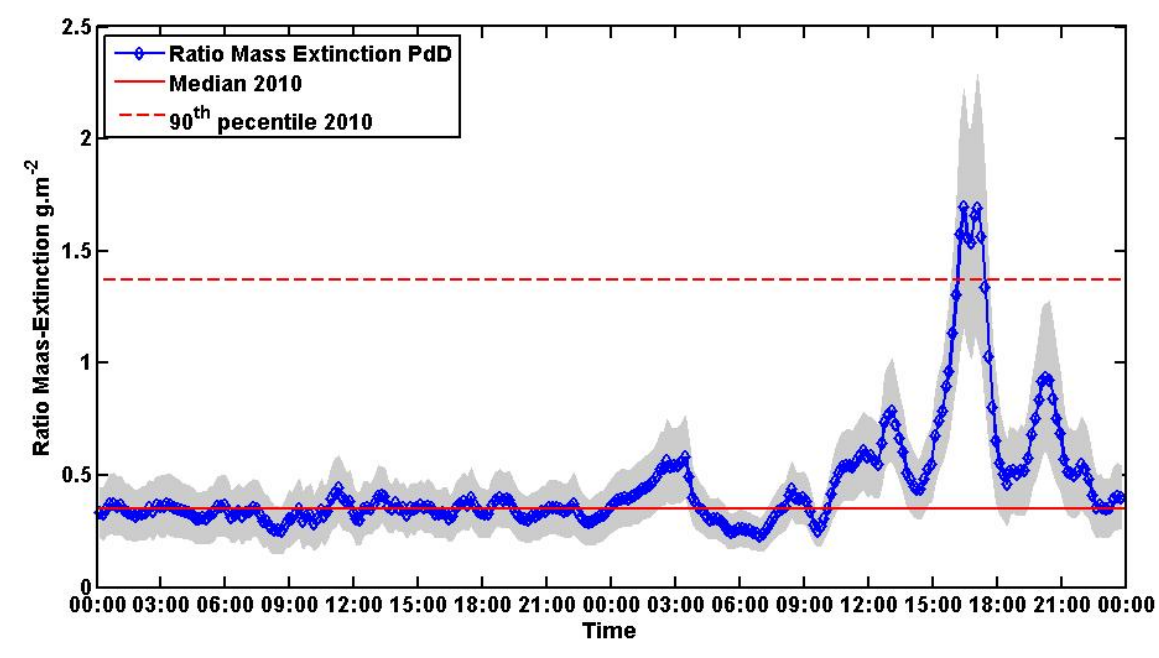

Fig. 5. Mass extinction ratio $\eta$ calculated at $355 \mathrm{~nm}$ for the 18 to 19 May 2010. The continuous red line represents the median and the dashed red line the 90th percentile calculated using all data for the year 2010.

(1.45 $\mathrm{g} \mathrm{m}^{-2}$ (Gasteiger et al., 2011). The inversion using combined photometer and Lidar data (Ansmann et al., 2011) gave a value of $1.57 \mathrm{~g} \mathrm{~m}^{-2}$ for the ashes and $0.265 \mathrm{~g} \mathrm{~m}^{-2}$ for the fine particles. Hence, the maximum value of the massto-extinction ratio measured at the PdD will be considered as representative of the volcanic particles and will be called $\eta_{\text {volcano }}$ in further calculations.

The large differences between $\eta$ outside and inside the ash plume demonstrates that $\eta$ is highly dependent on the aerosol properties and sensitive to varying mixtures between background aerosols and volcanic ash.

The $\eta$ values that we calculated from in situ measurements are for dry conditions (sampling relative humidity (RH) lower than $30 \%$ ). In order to apply $\eta$ to the Lidar extinction measurements, we would need to know $\eta$ for humid (ambient) conditions. A simplified theoretical study of the variation of $\eta$ with humidity can be performed. For an aerosol population with a mean diameter of $100 \mathrm{~nm}$ and a hygroscopic growth factor similar to the one of ammonium sulphate (i.e. as close as possible to the characteristics of the plume as it was detected at the Jungfraujoch, Bukowiecki et al., 2011 and at Mace head, O'Dowd et al., 2011), $\eta$ only increases by $30 \%$ when going from the dry state to a RH of $90 \%$. Consequently, $\eta$ calculated trough the PdD dry measurements can be applied to the Lidar inversion.

We did not applied any altitude dependence on the massto-extinction ratio. We are aware that the in situ volcanic ashes detected at the PdD are an approximation of the ashes located at $3000 \mathrm{~m}$. As $\eta$ depends only of the aerosol properties, we believe that it is good approximation.

If $\eta_{\text {volcano }}$ had not been appropriately estimated in the volcanic ash cloud, and instead the average value of $0.33 \mathrm{~g} \mathrm{~m}^{-2}$ had been used, the total particle mass retrieved would have been underestimated by roughly $80 \%$.

\subsubsection{Mass retrievals}

The retrieval of the particle mass was computed as described in Fig. 6. $\eta_{\text {volcano }}$ can be further used for particle mass retrievals in volcanic clouds when in situ measurements are not available (typically when the ash cloud is too high for even high altitude stations to sample it, and no airborne measurements are available). Inversions of the Lidar signal to compute the extinction was conducted under clear sky conditions following the procedure described in Sect. 2.2. The refractive index was calculated to be $1.52+0.008 i$ and the Lidar ratio $52 \pm 6 \mathrm{Sr}^{1}$.

For the volcanic cloud at $3000 \mathrm{~m}$ a.s.l., during the 19 May major event in clear sky condition from 12:00 to 16:00 UTC, the mass-to-extinction ratio for volcanic particles described in previous section was used $\left(\eta_{\text {volcano }}=\right.$ $1.57 \mathrm{~g} \mathrm{~m}^{-2}$ ). The computed extinction was found to be $474 \pm 18 \mathrm{Mm}^{-1}$ at $3000 \mathrm{~m}$ a.s.l. which corresponds to an ash mass of $744 \pm 29 \mu \mathrm{g} \mathrm{m}^{-3}$. Those values have the same order of magnitude as the mass and the extinction calculated by Ansmann and Gasteiger in Maisach, Germany, which are respectively $400-600 \mathrm{Mm}^{-1}$ and $\sim 1000 \mu \mathrm{g} \mathrm{m}^{-3}$ (Gasteiger et al., 2011; Ansmann et al., 2010).

To validate this inversion, the Lidar value obtained at the PdD height are compared with the in situ measurement: the extinction calculated from Lidar measurements at $1465 \mathrm{~m}$, between 12:00 and 16:00 UTC on 19 May is $927 \pm 153 \mathrm{Mm}^{-1}$ which correspond to a mass of $608 \pm 202 \mu \mathrm{g} \mathrm{m}^{-3}$ with the corresponding $\eta$. It is 10 times higher than the ash mass derived from TEOM measurements for the same period of time.

The difference between in situ and Lidar measurements can mostly be explained by the hygroscopic effect on the particle light extinction. Indeed, the simulated extinction calculated for the dry Particle Size Distribution (PSD) measured 


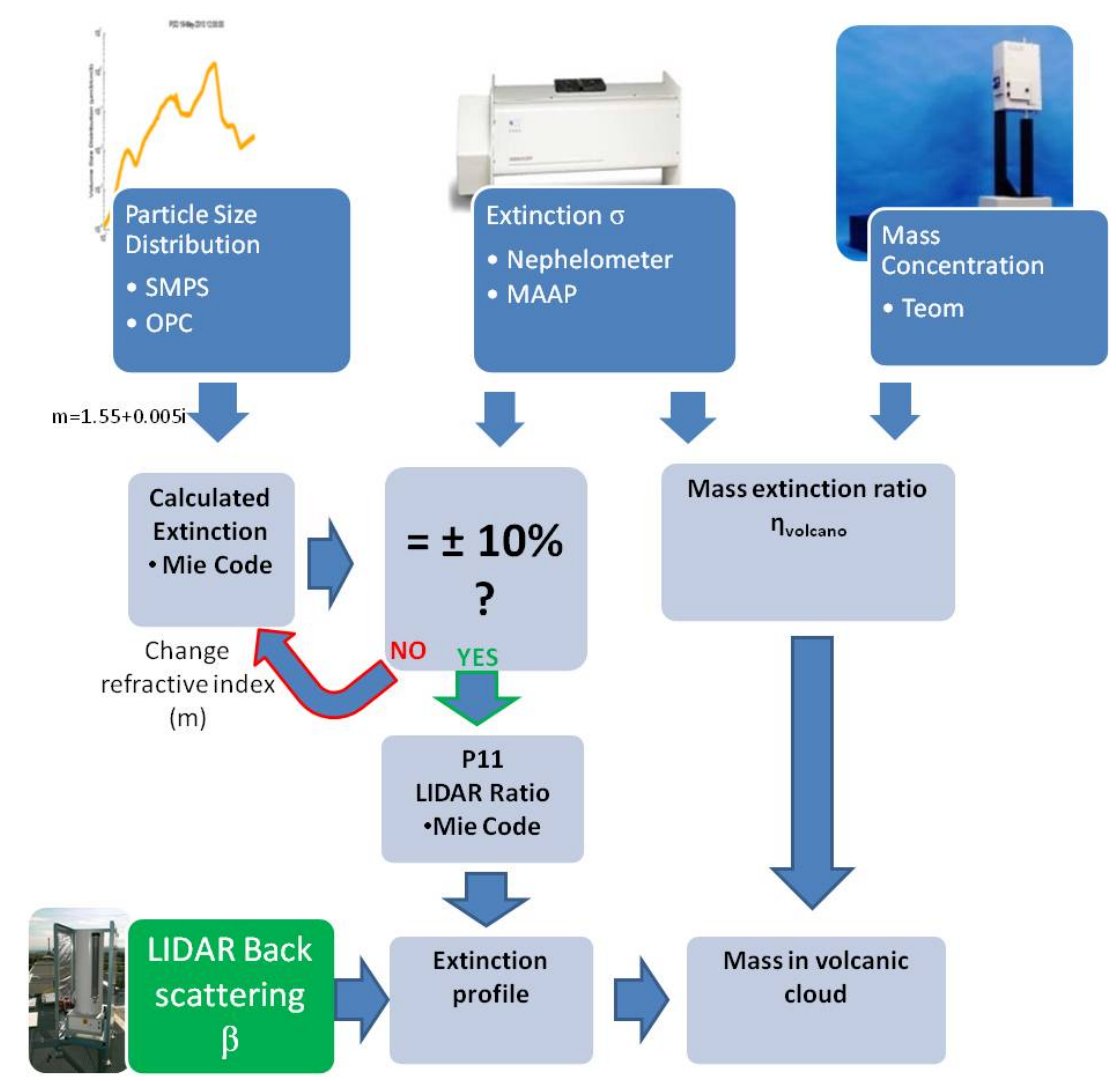

Fig. 6. Diagram of the volcanic mass retrieval. Dark-blue squares correspond to Puy de Dôme in situ measurements during the volcanic event, green to ground-based measurements, and light blue to calculated products.

with SMPS and GRIMM was $103 \pm 17 \mathrm{Mm}^{-1}$. The hygroscopic growth factor during volcanic events was found to be similar to the one of ammonium sulphate (O'Dowd et al., 2011; Wise et al., 2003; Bukowiecki et al., 2011). However pure ash particles are less hygroscopic (Lathem et al., 2011). Therefore we conducted the extinction calculation after performing a virtual hygroscopic growth of the measured PSD with a growth factor of 1.7 for the submicronic mode and 1.1 for the supermicronic. We found that the extinction of the hydrated PSD was $565 \pm 141 \mathrm{Mm}^{-1}$. Using this procedure we are able to explain $65 \%$ of the measured extinction instead of $17 \%$ for dry aerosol.

Similarly, the Lidar mass retrieval gives a much higher mass concentration than the FLEXPART simulation (Fig. 1), $655 \mu \mathrm{g} \mathrm{m}^{-3}$ compared to $176 \mu \mathrm{g} \mathrm{m}^{-3}$, which can be partly explained by the difference between dry and wet mass, and partly by the likely underestimation of the volcanic aerosol mass concentration simulations (cf. Sect. 3.1.3.). Moreover in-cloud sulphate production can contribute to difference between measurement and simulation. O'Dowd et al. (2011), measured of the order of $10 \mu \mathrm{g} \mathrm{m}^{-3}$ sulphate in the plume.

On the 18 May ashes were detected at 2300 to $3100 \mathrm{~m}$ a.s.l. From 06:00 to 07:00 UTC with a Lidar extinction of $502 \pm 46 \mathrm{Mm}^{-1}$. The mass concentration retrieved was
$788 \pm 79 \mu \mathrm{g} \mathrm{m}^{-3}$. It leads to an integrated total mass of $630400 \mu \mathrm{g} \mathrm{m}^{-2}$ in the plume. On the 19 May ashes were detected in the boundary layer. The mass retrieved was $608 \mathrm{\mu g} \mathrm{m}^{-3}$. If we consider a boundary layer thickness of $1800 \mathrm{~m}$ (from the ground to $2200 \mathrm{~m}$ a.s.l.), the total mass retrieved is $1094400 \mu \mathrm{g} \mathrm{m}^{-2}$. Corresponding to $57 \%$ of the mass measured previously. This mass is coherent with the in situ measurements presented in Sect. 3.1.3, were we show that the ashes represent roughly $60 \%$ of the total mass.

It is also consistent with the entrainment of volcanic ash into the boundary layer simulated by FLEXPART. However it is highly dependent of the heterogeneity of the ash layer and it cannot explain the mass concentration difference between Lidar and in situ measurements.

\subsection{Case 2: 18, 19 and 22 April 2010}

\subsubsection{Flexpart Simulation}

On 18 and 19 April, FLEXPART predicted an ash cloud over Clermont-Ferrand as shown in Fig. 7 and observed with the Lidar (Fig. 9). Figure 7 top panel presents the situation on 18 April simulated by FLEXPART. The ash was emitted mainly on 14-16 April, reached Central Europe on 16 April and was subsequently slowly transported to Western Europe and 

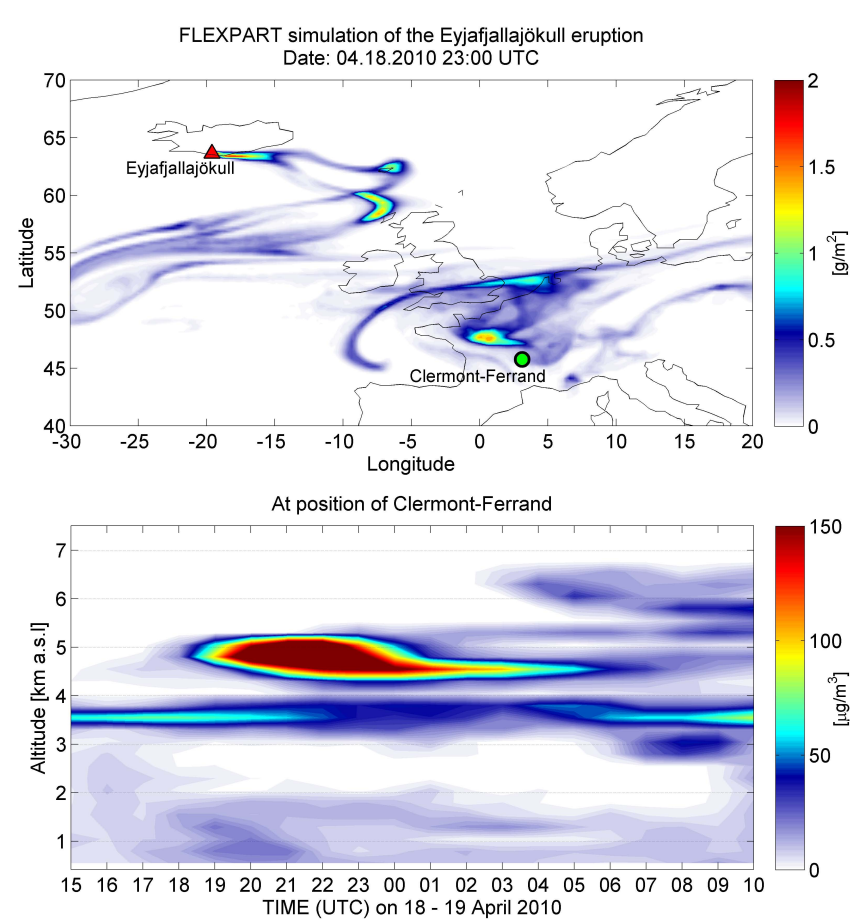

Fig. 7. FLEXPART simulated ash cloud. Total ash column load on 18 April 23:00 UTC (upper panel), and simulated vertical distribution of ash over Clermont-Ferrand for 18-19 April (lower panel).

resided mainly over France on 18 and 19 April (Stohl et al., 2011). The bottom panel presents the time series of the simulated ash mass over Clermont-Ferrand as function of altitude and time. Two layers at $3500 \mathrm{~m}$ and $4700 \mathrm{~m}$ a.s.l. are predicted. The $3500 \mathrm{~m}$ layer was simulated from 18 April at 15:00 UTC to 19 April at 09:00 UTC with mass concentrations around $50 \mu \mathrm{g} \mathrm{m}^{-3}$ This layer progressively became thicker with time, from a few hundred metres until a width of around $1 \mathrm{~km}$. The $4700 \mathrm{~m}$ layer was observed with a stronger intensity from 20:00 UTC on 18 April to 06:00 UTC on 19 April. At a maximum concentration of $247 \mu \mathrm{g} \mathrm{m}{ }^{-3}$, it was simulated with a thickness of $1 \mathrm{~km}$. The simulation shows a layer of lower concentration in the planetary boundary layer with a maximum concentration of $40 \mu \mathrm{g} \mathrm{m}^{-3}$.

Figure 8 represents the dispersion of ashes simulated by FLEXPART for 22 April. Ashes were simulated only in the PBL. The concentrations predicted are significantly lower than on 18 April with a maximum concentration of $18 \mu \mathrm{g} \mathrm{m}^{-3}$ at 06:00.

Lidar observations Figure 9 shows the depolarization ratio time series for 18-19 April where two highly depolarizing aerosol layers, indicating non-spherical particles, were detected at $4700 \mathrm{~m}$ and $3000 \mathrm{~m}$ a.s.l. The most depolarizing layer at $4700 \mathrm{~m}$ appears at 16:00 UTC, and was progressively dissipated in the morning of 19 April and had a maximum depolarization ratio of $17 \%$, while the layer at $3000 \mathrm{~m}$ reached a maximum depolarization ratio of 16\% between 05:00 a.m.
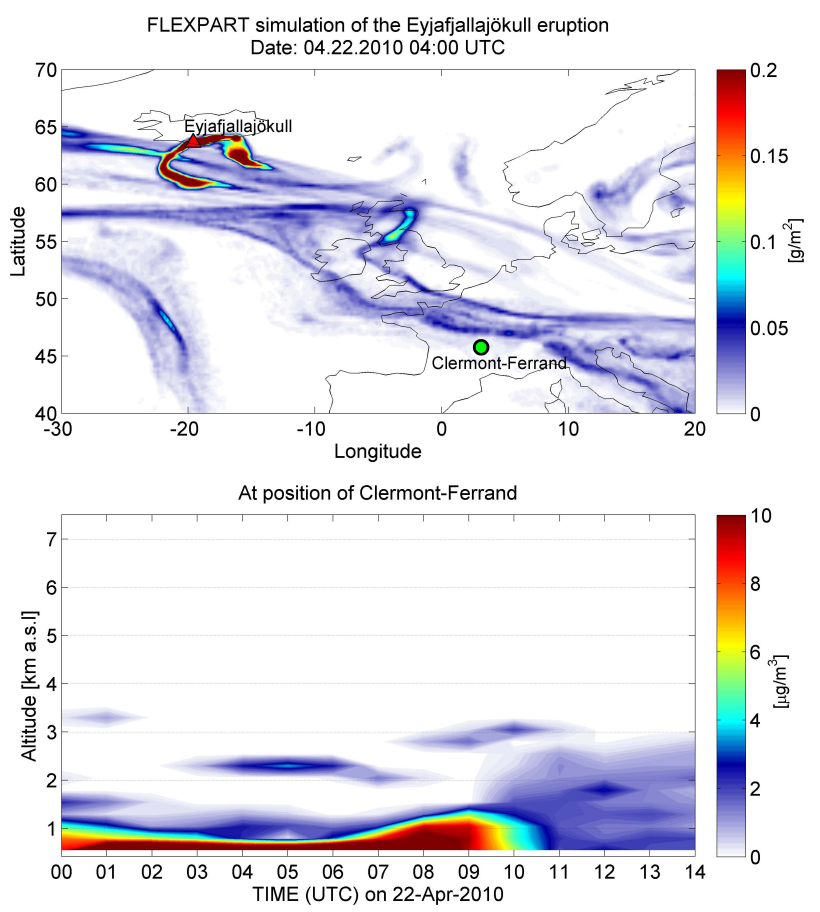

Fig. 8. FLEXPART simulated ash cloud. Total ash column load on 22 April 04:00 UTC (upper panel), and simulated vertical distribution of ash over Clermont-Ferrand for 22 April (lower panel).

and noon of 19 April. A low depolarizing layer observed at $1100 \mathrm{~m}$ is also visible.

The FLEXPART simulation (Fig. 7) shows high similarities with the Lidar measurements, but also some discrepancies. The layer detected at $3000 \mathrm{~m}$ was simulated by FLEXPART with the same thickness and time of occurrence. The appearance of the $4700 \mathrm{~m}$ layer is however observed about $5 \mathrm{~h}$ earlier with the Lidar than simulated by FLEXPART. Still, the altitude of the layer is well simulated. The layer detected at $1000 \mathrm{~m}$ a.s.l. by the Lidar has also been simulated at the same time but with a greater thickness. The simulation shows that the ash particles were mixed in the planetary boundary layer by the model but the Lidar observations show a strong stratification during the night and the presence of the depolarizing particles at a well delimited altitude. Insitu measurements at the PdD station did not show any strong signal that could indicate that the cloud entered the PBL, in agreement with the Lidar observations, and contrarily to the FLEXPART simulation. Some of the discrepancy between observations and simulation can be explained partly by the complex transport of the ash cloud. The ash was emitted 3-5 days earlier and transported slowly to Western Europe where it resided over France for a few days. This complicated and long-range transport of the emissions makes it difficult for the model to accurately simulate the ash distribution and can explain the $5 \mathrm{~h}$ time delay as well as the ash layer in the PBL not in accordance with the observations. 


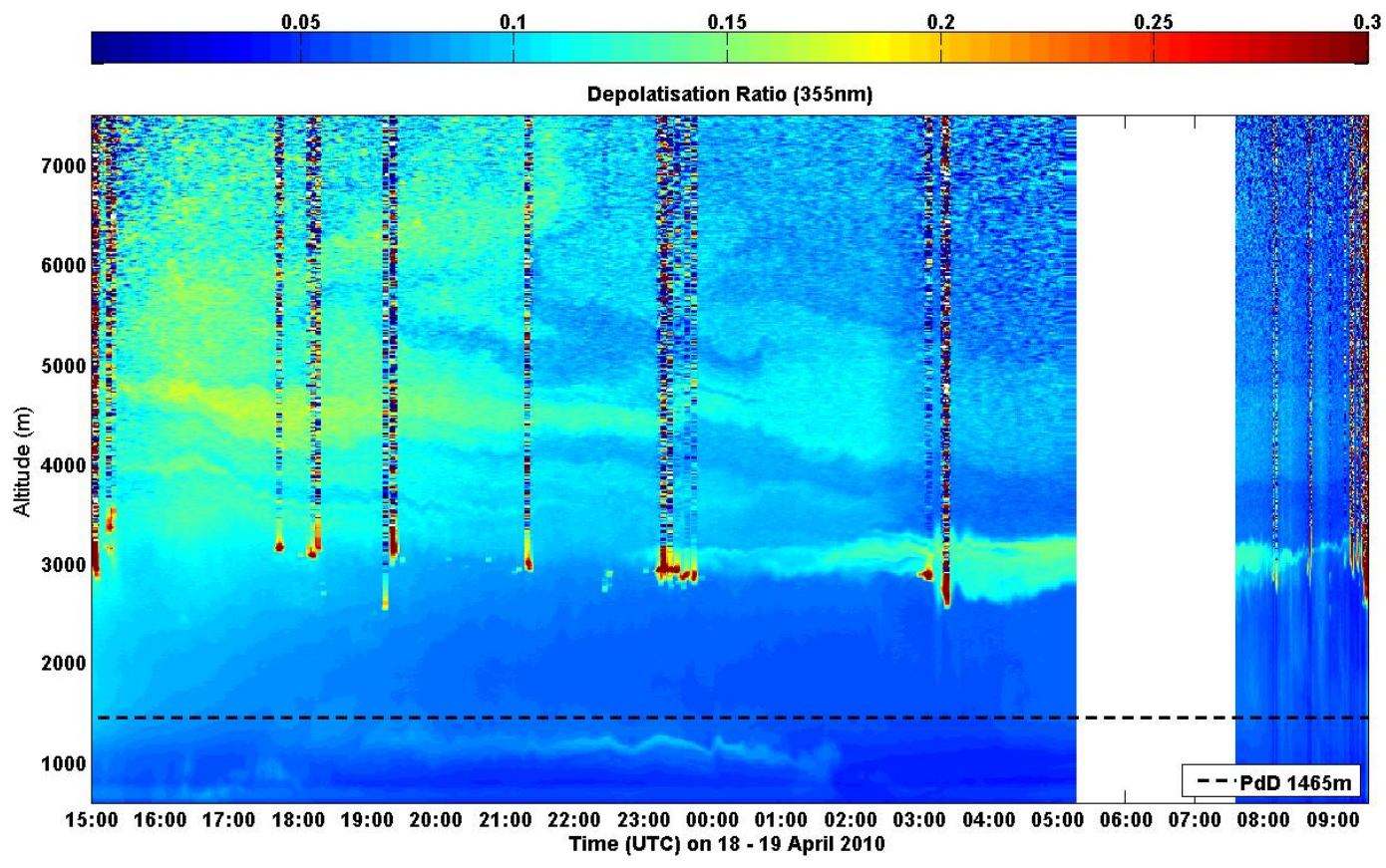

Fig. 9. Time series of the colour-coded volume depolarization ratio as a function of altitude for 18 to 19 April 2010. The black dotted line corresponds to the altitude of Puy de Dôme.

In comparison, for the May event previously shown, the ash transport was quicker and more directly towards the observation sites. This demonstrates the uncertainties in the model simulations, which increase with time during the ash transport from its source.

The Lidar depolarization ratio on 22 April in the early morning highlights the presence of altocumulus clouds between $4000 \mathrm{~m}$ and $7500 \mathrm{~m}$ (Fig. 10). After dissipation of the clouds at 06:30 UTC, a depolarizing signature was still present, at $5500 \mathrm{~m}$ and $4000 \mathrm{~m}$, probably ash from the Eyjafjalla eruption. However FLEXPART does not show any ash at this altitude hence, they might be other non-spherical particles such as dust particles transported during this period from Asian deserts (Uno et al., 2011)

At the top of the nocturnal boundary layer at $1000 \mathrm{~m}$, another ash layer was present from midnight to 04:00 UTC. At 09:00, non-spherical particles rose in the convective boundary layer and progressively reached $3000 \mathrm{~m}$. These nonspherical particles show a depolarization ratio which is lower (7\%) than the one measured directly in the ash cloud on 18 and 19 April (16\%). However, their presence corroborate the FLEXPART results showing ash traces in the PBL, and a low depolarization ratio might just indicate that ash particles are highly diluted and mixed with other background aerosol particles in the BL.

\subsubsection{Aircraft and ground-based measurements}

Four scientific flights were performed over France between 19 and 22 April mainly over Paris and Toulouse. On 22
April, the ATR-42 flew between Rouen and Toulouse. Only during this flight, the ATR-42 passed over Clermont-Ferrand between $700 \mathrm{~m}$ and $1700 \mathrm{~m}$, measuring in situ particle size distributions. The aircraft trajectory is presented in Fig. 11, with boundary layer measurement periods highlighted in red.

The FSSP 300 number size distribution measurements obtained along the flight track on 22 April are presented in Fig. 12a as a function of time. High particle concentrations both in the submicronic $(\sim 100 \mathrm{~nm})$ and in the supermicronic $(\sim 2 \mu \mathrm{m})$ modes are detected in the planetary boundary layer (PBL). While this is expected for the submicronic particles, coarse particles around $2 \mu \mathrm{m}$ are not usually found in the PBL to that extent $\left(1 \mathrm{~cm}^{-3}\right)$. This unusual mode was also measured during the previous flights performed over France and is suspected to be volcanic ash externally mixed in the PBL with pollution or sulphate particles formed from volcanic $\mathrm{SO}_{2}$, as also shown by the FLEXPART simulation at that time (Fig. 8). Figure 12b shows the mean aerosol number size distributions measured in the PBL over ClermontFerrand by PCASP (blue curve) and FSSP 300 (green curve) probes and by the OPC at the PdD station (red curve). FSSP and OPC measurements highlight the coarse mode mentioned above. Unlike on 18 and 19 April, a coarse mode aerosol was detected by OPC measurements at the PdD during the period from 20-22 April, when the volcanic ash had descended into the PBL.

The volume size distribution measurements at the OPC $2.5 \mu \mathrm{m}$ channel (Fig. 13) give a concentration of $0.8 \mathrm{~cm}^{-3}$ at 11:30 UTC on 22 April, when the airplane was over Clermont-Ferrand. This concentration exceeds the 90th 


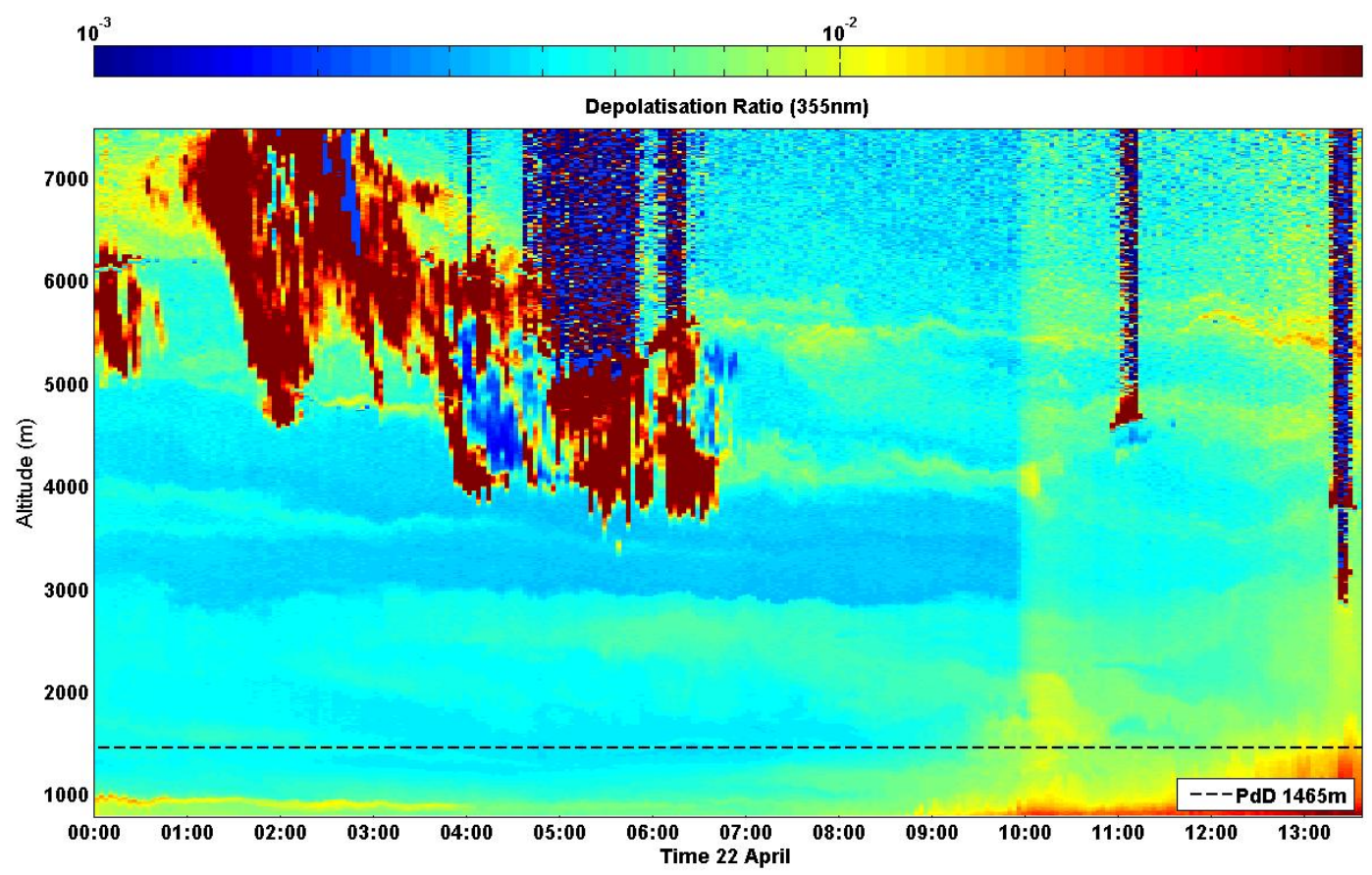

Fig. 10. Lidar volume depolarisation ratio on 22 April 00:00 to 13:30 UTC.

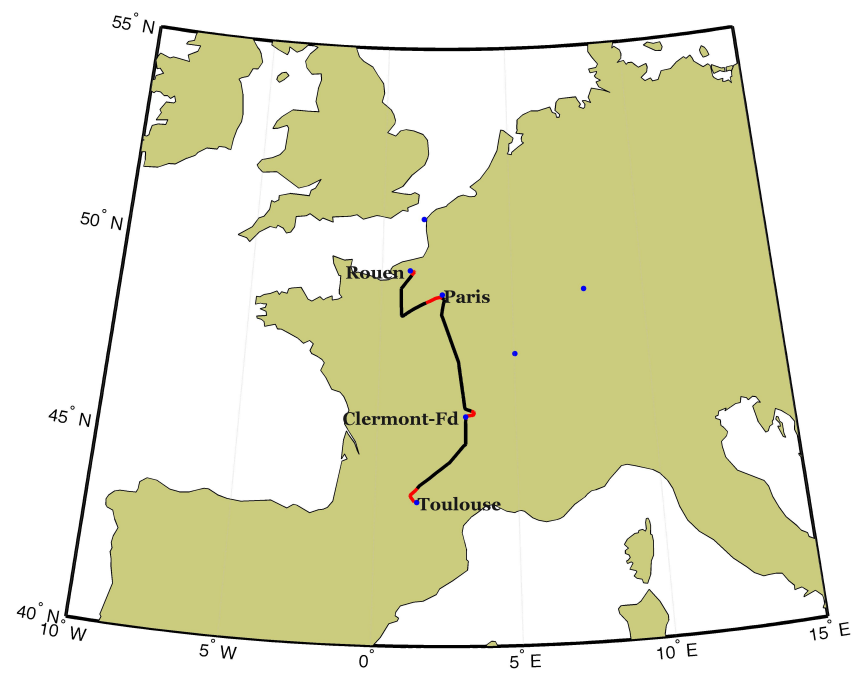

Fig. 11. ATR-42 trajectory on 22 April. Boundary layer measurement periods are highlighted in red.

percentile measured at the station in the year 2010 $\left(0.68 \mathrm{~cm}^{-3}\right)$ and is substantially higher than the annual median $\left(0.19 \mathrm{~cm}^{-3}\right)$. This $2 \mu \mathrm{m}$ mode was observed from 20 to 22 April, with still concentrations substantially higher than the annual median but lower than concentrations observed during the main volcanic events on 19 May (Fig. 4).

However the effective diameter is $280 \pm 20 \mathrm{~nm}$ from 18 to 22 April. It suggests that the volume size distribution is not dominated by the ashes but by the accumulation mode cen- tred on $350 \mathrm{~nm}$. Correspondingly, as already mentioned, the Lidar measured rather low depolarization ratio $(7 \%)$ on 22 April, compared to the ratio detected in the ash clouds on 18 and 19 April $(16 \%)$. This indicates that the ash concentrations were substantially lower on 22 April than on 18 and 19 April. It appears that volcanic ash transported to Europe at rather high altitudes subsided and eventually reached the PBL where it mixed with particles already present. During the four flights performed over France from 19 to 22 April, this coarse mode was always measured in the PBL but never in the FT.

The effective diameter calculated from FSSP airborne measurements is $0.6 \mu \mathrm{m}$. This is consistent with the airborne measurements in the Eyjafjalla cloud by the German DLR aircraft, which observed an effective diameter between 0.2 and $3 \mu \mathrm{m}$ (Schumann et al., 2011). This can be explained by the preferential removal of larger particles by gravitational settling. The ash cloud sampled on 22 April was particularly aged and mixed with ambient aerosol, thus, a small effective diameter is expected. Airborne PSD measurements lead to a mass of $21 \mu \mathrm{g} \mathrm{m}^{-3}$ with the OPAC density for transported mineral of $2.6 \mathrm{~g} \mathrm{~cm}^{-3}$ (Hess et al., 1998). This might be an underestimation as the smallest measured particle size was $0.1 \mu \mathrm{m}$.

The simultaneous in situ measurements at PdD, give a particle size distribution centred at $2.5 \mu \mathrm{m}$ with a mass concentration measured by the TEOM of $40 \mu \mathrm{g} \mathrm{m}^{-3}$ on 22 April at 11:30. Flentje et al. (2010) observed similar enhancement in Germany. The mass concentration did not show an important 

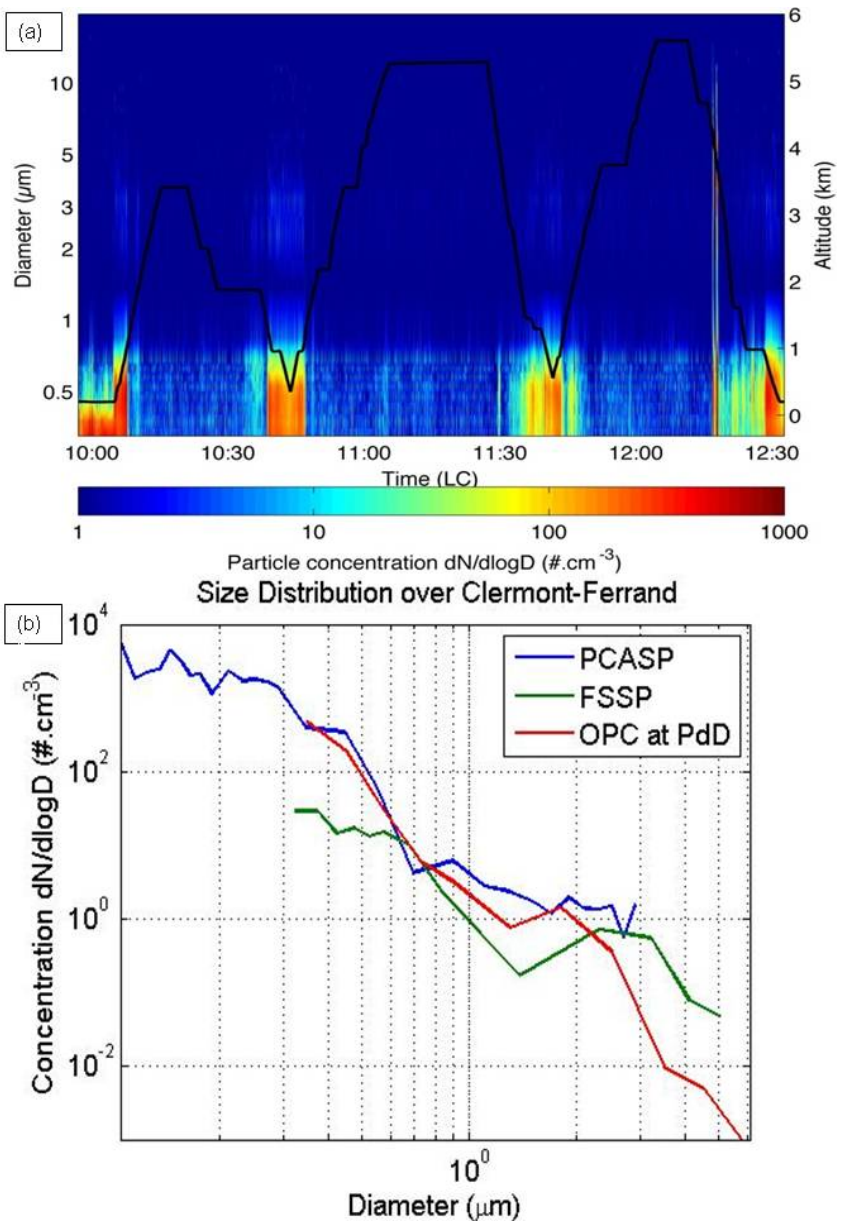

Fig. 12. Aircraft measurements on 22 April. Panel (a) presents the FSSP aerosol size distributions as a function of time. Particle number concentrations are colour-coded and the flight altitude is added in black. Plot (b) shows the mean aerosol size distributions in the PBL of Clermont-Ferrand measured during the overpass by the PCASP (in blue) and the FSSP (in green) and the ground-based OPC (in red).

variation on 22 April, when the volcanic plume was observed, and thus does not allow us to calculate the fraction of volcanic ashes. The mean scattering Ångström exponent $(\alpha)$ on 22 April was $1.99 \pm 0.09$. Thus the scattering was not dominated by the ash but by smaller particles. Consequently the calculated mass-to-extinction ratio $\eta$ was low compared to $\eta_{\text {volcano }}: 0.21 \pm 0.06 \mathrm{~g} \mathrm{~m}^{-2}$ instead of $1.42 \mathrm{~g} \mathrm{~m}^{-2}$.

\subsubsection{Mass retrievals}

The mass retrieval in the volcanic cloud on 19 April, from Lidar measurements (as described in Sect. 3.1.5) lead to a mean extinction of $369 \pm 38 \mathrm{Mm}^{-1}$ and a mass of $579 \pm 60 \mu \mathrm{g} \mathrm{m}^{-3}$ at $3000 \mathrm{~m}$ a.s.l. from 03:30 to 05:00 UTC.

Miffre et al. (2012) through a slightly different Lidar inversion retrieved an extinction of $187 \pm 34 \mathrm{Mm}^{-1}$ and a mass

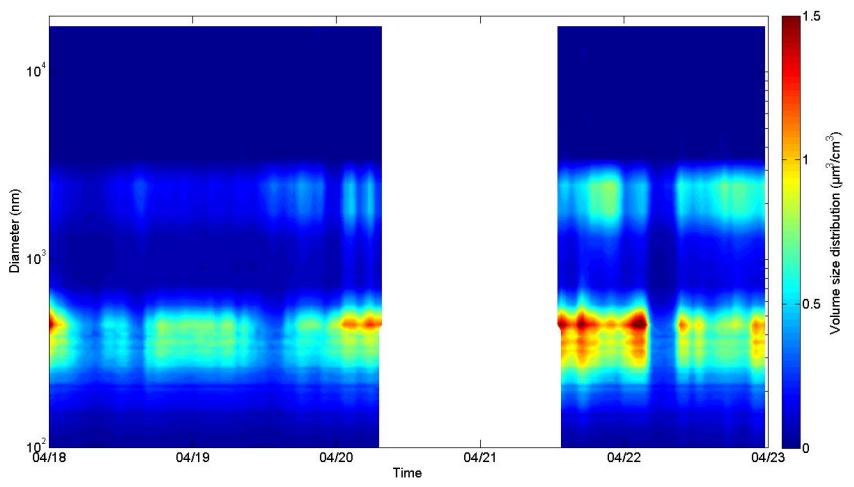

Fig. 13. Particle volume size distribution measured by a SMPS and Grimm OPC on 18-22 April 2010 at the Puy de Dôme.

concentration of $270 \pm 70 \mu \mathrm{g} \mathrm{m}^{-3}$ on 17 April over Lyon, $140 \mathrm{~km}$ east from Clermont-Ferrand (Miffre et al., 2012). On 19 April the mass concentration inverted was around $100 \mathrm{\mu g} \mathrm{m}^{-3}$ at $5000 \mathrm{~m}$. The difference between the mass concentration calculated by Miffre et al. (2012); and the one found in this study is mainly induced by a different $\mathrm{Li}$ dar backscatter measured: the Lidar ratio and the mass-toextinction ratio are nearly equal (55 against $52 \mathrm{Sr}^{-1}$ and 1.44 against $1.57 \mathrm{~g} \mathrm{~m}^{-2}$ ). This backscatter difference might be simply due to the inhomogeneity of the volcanic plume. On 22 April at 12:00, the extinction was $275 \pm 56 \mathrm{Mm}^{-1}$ at the height of PdD. The volcanic mass-to-extinction ratio $\eta_{\text {volcano }}$ cannot be applied in this case since ash was very diluted in the PBL. Moreover, both the low depolarization ratio, effective diameter and the high scattering Ångström exponent confirm the hypothesis that non-volcanic particles were dominant. Thus we used the mass-to-extinction ratio calculated at the same time. The mass retrieved is $54 \pm 9 \mu \mathrm{g} \mathrm{m}^{-3}$. It is slightly higher than the in situ measurements and can be explained by the hygroscopic growth of the particles.

FLEXPART concentrations are still lower than the mass derived from Lidar measurements and can be explained by both the presence of non-volcanic aerosols and by the fact that FLEXPART does not simulate hygroscopic growth of the particles and formation of secondary aerosols. Moreover the observations of the ash cloud over Germany from the 17 to 22 April highlight the fact that volcanic particles contributed, on average, only $30.2 \%$ of the total mass concentration (Pitz et al., 2011).

\section{Conclusions}

This paper presents in situ and ground-based remote-sensing measurements of the Eyjafjallajökull volcanic aerosol cloud in the free troposphere (FT) and Planetary Boundary Layer (PBL) over Clermont-Ferrand.

The highly depolarizing signature (indicating nonspherical particles) of volcanic ash was detected by Lidar on 
18 and 19 May at $3000 \mathrm{~m}$, and on 18, 19 and 22 April 2010, between 3000 and $4700 \mathrm{~m}$. The presence of ash simulated by FLEXPART agreed well with the observations, with small differences between simulated and observed altitudes of the ash cloud (shifted upward by $500 \mathrm{~m}$ in the model during the May event) or in the timing of the cloud arrival (shifted by $5 \mathrm{~h}$ in the model).

On both the May and April events, the ash cloud ended to enter the PBL, as shown both by the Lidar measurements and the FLEXPART simulation. Consequently, the ash could be observed with a suite of in situ measurement instruments at the Puy de Dôme (PdD 1465 m) station, which allowed us to characterise the microphysical and optical properties of the particles. In the ash clouds high $\mathrm{SO}_{2}$ concentrations were observed, which were not correlated with $\mathrm{NO}_{2}$ concentrations, thus confirming the volcanic origin of the air mass. The ground-based measurements showed that ash particles had a supermicronic mode around $2 \mu \mathrm{m}$, also detected at this size by airborne measurement during the April event.

During the May event, the concentration of particles with a diameter larger than $10 \mathrm{~nm}$ detected at the Puy de Dôme was up to $24000 \mathrm{~cm}^{-3}$, and the mass concentration reached $65 \mathrm{\mu g} \mathrm{m}^{-3}$. Volcanic particles are estimated to contribute around $60 \%$ of this mass during May. During the April event, the volcanic plume was too diluted to calculate the ash contribution. Comparison with the volcanic particle mass simulated with FLEXPART shows that the model underestimates the volcanic aerosol contribution by $33 \%$ in May. It can be partly explained by the formation of secondary particles not taken into account in the model.

Because the May event appeared to be much more impacted by ash particles when they entered the PBL, we used this data set to characterize the optical parameters of the ash. Dry extinction was up to $200 \mathrm{Mm}^{-1}$. The minimum of the Ångström coefficient (0.97) is indicative of coarse mode particles. The constant single scattering albedo of 0.97 does not suggest the ash to be strongly absorbing. Moreover, when the ash concentration appears the most concentrated, we calculate for the first time an in situ volcanic mass to extinction ratio $\eta$.

This ratio was then used for mass concentration inversion of volcanic ash with Lidar measurements. We found a mass concentration of $655 \pm 23 \mu \mathrm{g} \mathrm{m}^{-3}$ in May and $523 \pm 54 \mu \mathrm{g} \mathrm{m}^{-3}$ in April, which is clearly higher than the in situ mass concentrations. The discrepancy could be explained for $65 \%$ by the hygroscopic growth of the particles as seen by the Lidar, while the mass detected in situ is a dry mass.

Mass concentrations retrieved from the Lidar are also higher than the FLEXPART simulation and can be partly explained, again, by the hygroscopic growth of the particles and the formation of secondary aerosols, not taken into account in the simulation, and partly by the slight underestimation of the volcanic aerosol particle mass from the model simulations.
This work has shown that the time scale and localisation of simulated ash clouds agree relatively well with both remote sensing and in situ observations (ground-based and airborne), although simulations might be slightly underestimating the ash concentrations by $33 \%$. The coinciding remote sensing and ground-based measurements will allow for a better ash particle mass retrieval from Lidar soundings in the future, although some discrepancies still exist between in situ and remote sensing retrievals. At last, this study highlights the importance of taking into account the impact of given aerosol types hygroscopicity on light scattering, and also the need of a climatology of mass-to-extinction ratio to retrieve the aerosol mass from Lidar measurements.

Acknowledgements. The authors would like to acknowledge the OPGC and its staff for their efforts in establishing and maintaining the PdD measurement site and the SAFIRE team for their support in collecting airborne measurements.

Edited by: C. Bay Hasager

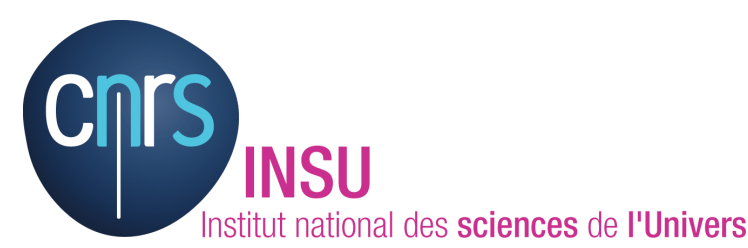

The publication of this article is financed by CNRS-INSU.

\section{References}

Anderson, T. and Ogren, J.: Determining Aerosol Radiative Properties Using the TSI 3563 Integrating Nephelometer, Aerosol Sci. Tech., 29, 57-69, 1998.

Anderson, T. L., Covert, D. S., Wheeler, J. D., Harris, J. M., Perry, K. D., Trost, B. E., Jaffe, D. J., and Ogren, J. A.: Aerosol backscatter fraction and single scattering albedo: Measured values and uncertainties at a coastal station in the Pacific Northwest, J. Geophys. Res.-Atmos., 104, 26793-26807, doi:10.1029/1999jd900172, 1999.

Ansmann, A., Tesche, M., Groß, S., Freudenthaler, V., Seifert, P., Hiebsch, A., Schmidt, J., Wandinger, U., Mattis, I., Müller, D., and Wiegner, M.: The 16 April 2010 major volcanic ash plume over central Europe: EARLINET lidar and AERONET photometer observations at Leipzig and Munich, Germany, Geophys. Res. Lett., 37, L13810, doi:10.1029/2010g1043809, 2010.

Ansmann, A., Tesche, M., Seifert, P., Groß, S., Freudenthaler, V., Apituley, A., Wilson, K. M., Serikov, I., Linné, H., Heinold, B., Hiebsch, A., Schnell, F., Schmidt, J., Mattis, I., Wandinger, U., and Wiegner, M.: Ash and fine-mode particle mass profiles from EARLINET-AERONET observations over central Europe after the eruptions of the Eyjafjallajökull volcano in 2010, J. Geophys. Res., 116, D00U02, doi:10.1029/2010jd015567, 2011.

Bockmann, C., Wandinger, U., Ansmann, A., Bosenberg, J., Amiridis, V., Boselli, A., Delaval, A., De Tomasi, F., Frioud, M., Grigorov, I. V., Hagard, A., Horvat, M., Iarlori, M., Komguem, 
L., Kreipl, S., Larchevque, G., Matthias, V., Papayannis, A., Pappalardo, G., Rocadenbosch, F., Rodrigues, J. A., Schneider, J., Shcherbakov, V., and Wiegner, M.: Aerosol lidar intercomparison in the framework of the EARLINET project. 2. Aerosol backscatter algorithms, Appl. Optics, 43, 977-989, doi:10.1364/ao.43.000977, 2004.

Bond, T. C., Habib, G., and Bergstrom, R. W.: Limitations in the enhancement of visible light absorption due to mixing state, J. Geophys. Res.-Atmos., 111, D20211, doi:10.1029/2006jd007315, 2006.

Boulon, J., Sellegri, K., Hervo, M., and Laj, P.: Observations of nucleation of new particles in a volcanic plume, P. Natl. Acad. Sci. USA, 108, 12223-12226, doi:10.1073/pnas.1104923108, 2011.

Bourcier, L.: Transport et dépôt des particules et radionucléides en France Thèse de 1'Université Blaise Pascal; spécialité: Physique de l'Atmosphère, Clermont-Ferrand, p., defended on 22 January 2009.

Bukowiecki, N., Zieger, P., Weingartner, E., Jurányi, Z., Gysel, M., Neininger, B., Schneider, B., Hueglin, C., Ulrich, A., Wichser, A., Henne, S., Brunner, D., Kaegi, R., Schwikowski, M., Tobler, L., Wienhold, F. G., Engel, I., Buchmann, B., Peter, T., and Baltensperger, U.: Ground-based and airborne in-situ measurements of the Eyjafjallajökull volcanic aerosol plume in Switzerland in spring 2010, Atmos. Chem. Phys., 11, 10011-10030, doi:10.5194/acp-11-10011-2011, 2011.

Casadevall, T. J.: The 1989-1990 eruption of redoubt volcano, Alaska - impacts on aircraft operations, J. Volcanol. Geotherm. Res., 62, 301-316, 1994.

Cuesta, J., Flamant, P. H., and Flamant, C.: Synergetic technique combining elastic backscatter lidar data and sunphotometer AERONET inversion for retrieval by layer of aerosol optical and microphysical properties, Appl. Optics, 47, 4598-4611, doi:10.1364/ao.47.004598, 2008.

Dubovik, O. and King, M. D.: A flexible inversion algorithm for retrieval of aerosol optical properties from Sun and sky radiance measurements, J. Geophys. Res.-Atmos., 105, 20673-20696, doi:10.1029/2000jd900282, 2000.

Dubovik, O., Holben, B., Eck, T. F., Smirnov, A., Kaufman, Y. J., King, M. D., Tanre, D., and Slutsker, I.: Variability of absorption and optical properties of key aerosol types observed in worldwide locations, J. Atmos. Sci., 59, 590-608, 2002.

Emeis, S., Forkel, R., Junkermann, W., Schäfer, K., Flentje, H., Gilge, S., Fricke, W., Wiegner, M., Freudenthaler, V., Groß, S., Ries, L., Meinhardt, F., Birmili, W., Münkel, C., Obleitner, F., and Suppan, P.: Measurement and simulation of the 16/17 April 2010 Eyjafjallajökull volcanic ash layer dispersion in the northern Alpine region, Atmos. Chem. Phys., 11, 2689-2701, doi:10.5194/acp-11-2689-2011, 2011.

Flentje, H., Claude, H., Elste, T., Gilge, S., Köhler, U., PlassDülmer, C., Steinbrecht, W., Thomas, W., Werner, A., and Fricke, W.: The Eyjafjallajökull eruption in April 2010 - detection of volcanic plume using in-situ measurements, ozone sondes and lidar-ceilometer profiles, Atmos. Chem. Phys., 10, 1008510092, doi:10.5194/acp-10-10085-2010, 2010.

Gasteiger, J., Groß, S., Freudenthaler, V., and Wiegner, M.: Volcanic ash from Iceland over Munich: mass concentration retrieved from ground-based remote sensing measurements, Atmos. Chem. Phys., 11, 2209-2223, doi:10.5194/acp-11-22092011, 2011.
Giannakaki, E., Balis, D. S., Amiridis, V., and Zerefos, C.: Optical properties of different aerosol types: seven years of combined Raman-elastic backscatter lidar measurements in Thessaloniki, Greece, Atmos. Meas. Tech., 3, 569-578, doi:10.5194/amt-3569-2010, 2010.

Labazuy, P., Gouhier, M., Harris, A., Guéhenneux, Y., Hervo, M., Bergès, J. C., Fréville, P., Cacault, P., and Rivet, S.: Near real-time monitoring of the April-May 2010 Eyjafjallajökull ash cloud: an example of a web-based, satellite-data-driven, reporting system, Int. J. Environ. Pollut., in review, 2012.

Grover, B. D., Kleinman, M., Eatough, N. L., Eatough, D. J., Hopke, P. K., Long, R. W., Wilson, W. E., Meyer, M. B., and Ambs, J. L.: Measurement of total PM(2.)5 mass (nonvolatile plus semivolatile) with the Filter Dynamic Measurement System tapered element oscillating microbalance monitor, J. Geophys. Res.-Atmos., 110, D07s03, doi:10.1029/2004jd004995, 2005.

Hess, M., Koepke, P., and Schult, I.: Optical properties of aerosols and clouds: The software package OPAC, B. Am. Meteorol. Soc., 79, 831-844, 1998.

Klett, J. D.: Lidar inversion with variable backscatter extinction ratios, Appl. Optics, 24, 1638-1643, 1985.

Lathem, T. L., Kumar, P., Nenes, A., Dufek, J., Sokolik, I. N., Trail, M., and Russell, A.: Hygroscopic properties of volcanic ash, Geophys. Res. Lett., 38, L11802, doi:10.1029/2011g1047298, 2011.

Lettino, A., Caggiano, R., Fiore, S., Macchiato, M., Sabia, S., and Trippetta, S.: Eyjafjallajökull volcanic ash in southern Italy, Atmos. Environ., 48, 97-103, doi:10.1016/j.atmosenv.2011.05.037, 2012.

Matthais, V., Freudenthaler, V., Amodeo, A., Balin, I., Balis, D., Bosenberg, J., Chaikovsky, A., Chourdakis, G., Comeron, A., Delaval, A., De Tomasi, F., Eixmann, R., Hagard, A., Komguem, L., Kreipl, S., Matthey, R., Rizi, V., Rodrigues, J. A., Wandinger, U., and Wang, X.: Aerosol lidar intercomparison in the framework of the EARLINET project. 1. Instruments, Appl. Optics, 43, 961-976, doi:10.1364/ao.43.000961, 2004.

Mätzler, C.: MATLAB functions for Mie scattering and absorption, Research Report 2002-2008, Institut für Angewandte Physik, Bern, 2002.

Miffre, A., David, G., Thomas, B., Rairoux, P., Fjaeraa, A. M., Kristiansen, N. I., and Stohl, A.: Volcanic aerosol optical properties and phase partitioning behavior after long-range advection characterized by UV-Lidar measurements, Atmos. Environ., 48, 76-84, doi:10.1016/j.atmosenv.2011.03.057, 2012.

Mona, L., Amodeo, A., D’Amico, G., Giunta, A., Madonna, F., and Pappalardo, G.: Multi-wavelength Raman lidar observations of the Eyjafjallajökull volcanic cloud over Potenza, Southern Italy, Atmos. Chem. Phys. Discuss., 11, 12763-12803, doi:10.5194/acpd-11-12763-2011, 2011.

Nehrir, A. R., Repasky, K. S., Reagan, J. A., and Carlsten, J. L.: Optical characterization of continental and biomassburning aerosols over Bozeman, Montana: A case study of the aerosol direct effect, J. Geophys. Res.-Atmos., 116, D21201, doi:10.1029/2011jd016016, 2011.

O’Dowd, C., Ceburnis, D., Ovadnevaite, J., Martucci, G., Bialek, J., Monahan, C., Berresheim, H., Vaishya, A., Grigas, T., Jennings, S. G., McVeigh, P., Varghese, S., Flanagan, R., Martin, D., Moran, E., Lambkin, K., Semmler, T., Perrino, C., and McGrath, R.: The Eyjafjallajökull ash plume - Part I: Physical, 
chemical and optical characteristics, Atmos. Environ., 48, 129142, doi:10.1016/j.atmosenv.2011.07.004, 2011.

Papayannis, A., Balis, D., Amiridis, V., Chourdakis, G., Tsaknakis, G., Zerefos, C., Castanho, A. D. A., Nickovic, S., Kazadzis, S., and Grabowski, J.: Measurements of Saharan dust aerosols over the Eastern Mediterranean using elastic backscatter-Raman lidar, spectrophotometric and satellite observations in the frame of the EARLINET project, Atmos. Chem. Phys., 5, 2065-2079, doi:10.5194/acp-5-2065-2005, 2005.

Petzold, A., Schloesser, H., Sheridan, P. J., Arnott, W. P., Ogren, J. A., and Virkkula, A.: Evaluation of Multiangle Absorption Photometry for Measuring Aerosol Light Absorption, Aerosol Sci. Tech., 39, 40-51, 2005.

Pitz, M., Gu, J., Soentgen, J., Peters, A., and Cyrys, J.: Particle size distribution factor as an indicator for the impact of the Eyjafjallajökull ash plume at ground level in Augsburg, Germany, Atmos. Chem. Phys., 11, 9367-9374, doi:10.5194/acp-11-93672011, 2011.

Prata, A. and Tupper, A.: Aviation hazards from volcanoes: the state of the science, Nat. Hazards, 51, 239-244, doi:10.1007/s11069009-9415-y, 2009.

Raut, J. C. and Chazette, P.: Retrieval of aerosol complex refractive index from a synergy between lidar, sunphotometer and in situ measurements during LISAIR experiment, Atmos. Chem. Phys., 7, 2797-2815, doi:10.5194/acp-7-2797-2007, 2007.

Raut, J. C. and Chazette, P.: Assessment of vertically-resolved $\mathrm{PM}_{10}$ from mobile lidar observations, Atmos. Chem. Phys., 9, 8617-8638, doi:10.5194/acp-9-8617-2009, 2009.

Revuelta, M. A., Sastre, M., Fernández, A. J., Martín, L., García, R., Gómez-Moreno, F. J., Artíñano, B., Pujadas, M., and Molero, F.: Characterization of the Eyjafjallajökull volcanic plume over the Iberian Peninsula by lidar remote sensing and ground-level data collection, Atmos. Environ., 48, 46-55, doi:10.1016/j.atmosenv.2011.05.033, 2012

Ruppecht, E., Meyer, M., and Patashnick, H.: The tapered element oscillating microbalance as a tool for measuring ambient particulate concentrations in real time, J. Aerosol Sci., 23, Supplement 1, 635-638, 1992.

Russell, P. B., Bergstrom, R. W., Shinozuka, Y., Clarke, A. D., DeCarlo, P. F., Jimenez, J. L., Livingston, J. M., Redemann, J., Dubovik, O., and Strawa, A.: Absorption Angstrom Exponent in AERONET and related data as an indicator of aerosol composition, Atmos. Chem. Phys., 10, 1155-1169, doi:10.5194/acp10-1155-2010, 2010.

Sassen, K., Zhu, J., Webley, P., Dean, K., and Cobb, P.: Volcanic ash plume identification using polarization lidar: Augustine eruption, Alaska, Geophys. Res. Lett., 34, L08803, doi:10.1029/2006g1027237, 2007.

Schäfer, K., Thomas, W., Peters, A., Ries, L., Obleitner, F., Schnelle-Kreis, J., Birmili, W., Diemer, J., Fricke, W., Junkermann, W., Pitz, M., Emeis, S., Forkel, R., Suppan, P., Flentje, H., Gilge, S., Wichmann, H. E., Meinhardt, F., Zimmermann, R., Weinhold, K., Soentgen, J., Münkel, C., Freuer, C., and Cyrys, J.: Influences of the 2010 Eyjafjallajökull volcanic plume on air quality in the northern Alpine region, Atmos. Chem. Phys., 11, 8555-8575, doi:10.5194/acp-11-8555-2011, 2011.

Schumann, U., Weinzierl, B., Reitebuch, O., Schlager, H., Minikin, A., Forster, C., Baumann, R., Sailer, T., Graf, K., Mannstein, H., Voigt, C., Rahm, S., Simmet, R., Scheibe, M., Lichtenstern,
M., Stock, P., Rüba, H., Schäuble, D., Tafferner, A., Rautenhaus, M., Gerz, T., Ziereis, H., Krautstrunk, M., Mallaun, C., Gayet, J. F., Lieke, K., Kandler, K., Ebert, M., Weinbruch, S., Stohl, A., Gasteiger, J., Groß, S., Freudenthaler, V., Wiegner, M., Ansmann, A., Tesche, M., Olafsson, H., and Sturm, K.: Airborne observations of the Eyjafjalla volcano ash cloud over Europe during air space closure in April and May 2010, Atmos. Chem. Phys., 11, 2245-2279, doi:10.5194/acp-11-2245-2011, 2011.

Sigmundsson, F., Hreinsdottir, S., Hooper, A., Arnadottir, T., Pedersen, R., Roberts, M. J., Oskarsson, N., Auriac, A., Decriem, J., Einarsson, P., Geirsson, H., Hensch, M., Ofeigsson, B. G., Sturkell, E., Sveinbjornsson, H., and Feigl, K. L.: Intrusion triggering of the 2010 Eyjafjallajokull explosive eruption, Nature, 468, 426-430, doi:10.1038/nature09558, 2010.

Soltic, P. and Weilenmann, M.: $\mathrm{NO}_{2} / \mathrm{NO}$ emissions of gasoline passenger cars and light-duty trucks with Euro2 emission standard, Atmos. Environ., 37, 5207-5216, doi:10.1016/j.atmosenv.2003.05.003, 2003.

Stohl, A., Forster, C., Frank, A., Seibert, P., and Wotawa, G.: Technical note: The Lagrangian particle dispersion model FLEXPART version 6.2, Atmos. Chem. Phys., 5, 2461-2474, doi:10.5194/acp-5-2461-2005, 2005.

Stohl, A., Prata, A. J., Eckhardt, S., Clarisse, L., Durant, A., Henne, S., Kristiansen, N. I., Minikin, A., Schumann, U., Seibert, P., Stebel, K., Thomas, H. E., Thorsteinsson, T., Tørseth, K., and Weinzierl, B.: Determination of time- and height-resolved volcanic ash emissions and their use for quantitative ash dispersion modeling: the 2010 Eyjafjallajökull eruption, Atmos. Chem. Phys., 11, 4333-4351, doi:10.5194/acp-11-4333-2011, 2011.

Thomas, H. E. and Prata, A. J.: Sulphur dioxide as a volcanic ash proxy during the April-May 2010 eruption of Eyjafjallajökull Volcano, Iceland, Atmos. Chem. Phys., 11, 6871-6880, doi:10.5194/acp-11-6871-2011, 2011.

Uno, I., Eguchi, K., Yumimoto, K., Liu, Z., Hara, Y., Sugimoto, N., Shimizu, A., and Takemura, T.: Large Asian dust layers continuously reached North America in April 2010, Atmos. Chem. Phys., 11, 7333-7341, doi:10.5194/acp-11-7333-2011, 2011.

Venzac, H., Sellegri, K., Villani, P., Picard, D., and Laj, P.: Seasonal variation of aerosol size distributions in the free troposphere and residual layer at the puy de Dôme station, France, Atmos. Chem. Phys., 9, 1465-1478, doi:10.5194/acp-9-1465-2009, 2009.

Villani, P., Picard, D., Michaud, V., Laj, P., and Wiedensohler, A.: Design and validation of a volatility hygroscopic tandem differential mobility analyzer (VH-TDMA) to characterize the relationships between the thermal and hygroscopic properties of atmospheric aerosol particles, Aerosol Sci. Technol., 42, 729-741, doi:10.1080/02786820802255668, 2008.

Wagner, F. and Silva, A. M.: Some considerations about Ångström exponent distributions, Atmos. Chem. Phys., 8, 481-489, doi:10.5194/acp-8-481-2008, 2008.

Weitkamp, C.: Lidar: range-resolved optical remote sensing of the atmosphere, Springer Science+Business Media, 2005.

Wise, M. E., Surratt, J. D., Curtis, D. B., Shilling, J. E., and Tolbert, M. A.: Hygroscopic growth of ammonium sulfate/dicarboxylic acids, J. Geophys. Res., 108, 4638, doi:10.1029/2003jd003775, 2003.

WMO: WMO/GAW Aerosol Measurement procedures guidelines and recommendations, WMO TD, No. 1178, 2003. 